\title{
Income Diversification Strategies of Italian Peri-Urban Farms: A Structural Equation Modeling Approach
}

\author{
Orlando Cimino (D), Marco Vassallo (D), Roberto Henke (D) and Francesco Vanni *(D) \\ CREA-Research Centre for Agricultural Policies and Bioeconomy, 00198 Rome, Italy; \\ orlando.cimino@crea.gov.it (O.C.); marco.vassallo@crea.gov.it (M.V.); roberto.henke@crea.gov.it (R.H.) \\ * Correspondence: francesco.vanni@crea.gov.it
}

\begin{abstract}
On-farm diversification in non-agricultural activities has been increasingly recognized as a rewarding farm strategy through which farmers produce on-farm non-agricultural goods and services. The main objective of this paper is to explore to what extent the condition of peri-urbanity affects farm income diversification in Italy by looking at the push and pull factors that allow peri-urban farmers to re-organize their business by developing diversification strategies that are tightly connected to the demand of goods and services coming from the urban society. A structural equation modeling (SEM) statistical technique has been applied to estimate direct and indirect causal relationships among the multiple variables involved. The SEM analytical approach allowed us to untie the complexity of the push and pull factors connections and to highlight the most significant ones. The strengths of the structural paths provide evidence on the key diversification strategies adopted by peri-urban farms.
\end{abstract}

Keywords: on-farm diversification; peri-urban farms; structural equation modeling; FADN

Citation: Cimino, O.; Vassallo, $\mathrm{M}$.

Henke, R.; Vanni, F. Income

Diversification Strategies of Italian Peri-Urban Farms: A Structural

Equation Modeling Approach. Land 2021, 10, 790. https://doi.org/

10.3390/land 10080790

Academic Editor: Elisa Marraccini

Received: 18 June 2021

Accepted: 23 July 2021

Published: 28 July 2021

Publisher's Note: MDPI stays neutral with regard to jurisdictional claims in published maps and institutional affiliations.

\section{Introduction}

On-farm diversification in non-agricultural activities (hereafter only diversification) has been increasingly recognized as a rewarding farm strategy through which farmers produce on-farm non-agricultural goods and services. In doing so, farmers employ farm inputs (capital, labor, and land) in new products or in products that incorporate added services, with the aim to reach new markets and increase their income, diversifying, at the same time, the sources of revenues [1,2]. This definition of diversification is concerned with the activities undertaken at the farm business level, using the farm's resources that are outside the range of conventional crop and livestock production. A concept that should not be confused with diversification is pluri-activity, which focuses on the external activities of farmers and is based on the "diversified" sources of income for the farm household available off-farm. Diversification is a direct consequence of the conceptualization of multifunctionality and the multifunctional role of agriculture in the economic literature [3]. Multifunctionality has become key to a renovated role of agriculture and rural areas in the European and other developed contexts and has brought an increasing interest to the issue of structural change in agriculture and new forms of on-farm non-agricultural use of farmland $[4,5]$.

Diversification is largely acknowledged to be a key adaptation strategy for farmers to adjust to market dynamics and on-going political changes [6,7]. It allows farmers to occupy extra family labor within the farm activities and to reduce economic risk in their business. Once multifunctionality has been fully recognized as a specific feature of the European agricultural model, farmers have increasingly been aware of the potential source of growth, efficiency, and reduction of business risk in it, especially for small size and family-based units [7]. Such potential is highly influenced by many factors, internal as well as external to the farm, localization being one of the most relevant and one of the most investigated. However, the specific condition of peri-urbanity is often neglected as a pre-determined conceptual category that is external to the rural and professional 
agricultural world. It is rather conceived as a temporary condition farms adapt to, given the external drivers of change.

The literature dealing with the reasons behind diversification distinguishes among "pull" and "push" factors [3,8-10]. Pull factors can be considered opportunity driven factors: farmers start on-farm non-agricultural activities because they see a business opportunity in them and decide to re-allocate existing resources to gain business growth. Examples of pull factors are the (higher) profitability of the diversification activities and the demand for new goods and services expressed by consumers. In this case, diversification is undertaken as an explicitly business strategy and for accumulation objectives. Push factors can be defined as necessity driven factors, including all the conditions that cause pressure on the farm due to external shocks, structural crises, and the consequent decline of income. In this case farmers will choose to diversify to manage risk, to cope with external shocks, to deal with surplus household labor and seasonality, and more in general, to secure family income.

The main objective of this paper is to explore to what extent the condition of periurbanity affects farms income diversification by looking at the specific push and pull factors that allow peri-urban farmers to re-organize their business by developing diversification strategies.

The paper aims at contributing to the literature in two ways.

First, the literature on push/pull factors usually focuses on income diversification strategies outside agriculture, namely, on how farmers reallocate existing resources towards non-farm income diversification [8,11-13]. This reallocation can be "opportunity driven" (pull factor) or "necessity driven" (push factor) [10,14]. Conversely, in this article factors are divided into push and pull ones according to the direction they drive on-farm diversification. Diversification may be undertaken as an explicitly business strategy, aimed at accumulation when driven by "pull factors"; on the opposite side, farms may diversify as a reaction to "push factors" that drive risk or external shocks, seeking to escape from stagnation and decline. Both push and pull factors were distinguished between two observation levels: the farm (micro) level and the context (meso) level [10]. For instance, farm size and labor are capacity variables at the household level, whereas proximity to urban centers is a regional-level capacity.

The second contribution is related to the focus on the role of such factors for the diversification of peri-urban farms. Although the multifunctionality of peri-urban farming has been increasingly investigated [15], to date there is little evidence on the role of push and pull factors driving the on-farm diversification process of peri-urban agriculture. This phenomenon has been investigated mainly through case studies and qualitative analysis [3,16-18].

More specifically, the article aims at testing the following hypotheses:

Hypothesis 1 (H1). Peri-urbanity is a key context feature that influences the combination and weight of push and pull factors driving on-farm diversification.

Hypothesis 2 (H2). Peri-urbanity may change the relations and the intensity of both pull and push factors.

To test the aforementioned hypotheses, after the identification of the key push and pull factors influencing on-farm income diversification of Italian family farms, a theoryoriented causal path model was proposed and estimated by means of a structural equation modeling (SEM) data analytical approach $[19,20]$. This model was applied to Italian Farm Accountancy Data Network (FADN) data for the years 2008, 2013, and 2018 and it allowed us to assess the relevance of push and pull factors-also divided into external (context) and internal (farm level) factors-in influencing on-farm income diversification and their evolution over time. 


\section{Literature Review}

\subsection{On Farm Diversification}

The multifunctional role of agriculture in contemporary societies has put the primary sector under a different spot about its capacity to produce income and wealth. While it was commonly accepted that primary activities contributed only for a marginal and decreasing share to the gross product of an economic system, the process of diversification activated by a multifunctional approach and by the support provided by the CAP has given a new impulse to the primary sector and to its contribution to the general wealth. Boncinelli et al. [21] report in their work how several European countries, between 2005 and 2015, saw their production in secondary activities (including good and services) increasing by almost $5 \%$ per year, while agricultural production at basic values had grown only slightly more than $2 \%$.

Diversification implies that production factors (labor, land, capital) are moved away from the original main agricultural activity and towards new activities. The more the production factors are diverted from the main production function, the more farms become diversified. Consequently, one of the topics often investigated by some recent papers is the extent to which diversification can divert resources for the proper agricultural activity to other gainful ones and the decision-making process that leads to the optimal factor allocation. For example, Boncinelli et al. [21] investigate this process with regards to labor, highlighting how small farms have serious issues with allocating a proper amount of labor into new activities, so their decision to diversify is strongly constrained by that, while larger farms have a wider potential in devoting resources in favor of new activities. Other structural factors investigated in literature are farm size, geographical location, and spatial connections $[9,22]$. Other relevant factors, largely investigated in the recent literature, are entrepreneurship and policies enhancing diversification [6,23-26].

Yoshida et al. [23] analyze, among others, entrepreneurship as one of the main determinants of farm diversification. They focus on the relevance of the farmers' skills in exploring and making new activities successful in their business. According to the authors, management capabilities are key to succeeding in the new activities; however, in small family farms, such entrepreneurial skills might not be sufficiently developed within the household. Entrepreneurship plays an important role in the process of farm diversification, mainly in recognizing, evaluating, and exploiting opportunities to diversify existing businesses and in developing the operational capabilities needed for entering a new business.

Morris et al. [24] propose a conceptual framework based on the attitudes towards on- and off-farm diversification, focusing on Welsh farms. According to the authors, entrepreneurship as a theoretical interpretative category does not really apply to famers since they operate in a heavily subsidized environment and not in a genuinely competitive market. Farmers have been traditionally played in the business arena as price-takers, market followers, and passive decision makers, failing to behave according to the basic rules of entrepreneurship. However, entrepreneurship, in the diversification activity, may be critical for the survival of contemporary family-managed businesses. The search for innovation and the use of updated technology in a competitive market are keys to success, so the authors rightfully recognize the need of a clearer focus to the entrepreneurial skills of the diversifying farmers.

Yoshida et al. [23] also investigate policies as another determining factor for farm diversification. The lack of entrepreneurship among farmers has been often considered an obstacle for sustainable rural policies under the recent CAP. Their findings indicate that future reforms of the CAP should do more to promote specific programs to build entrepreneurial skills, which so far are substantially neglected in the allocation of the CAP financial resources.

The relationship between diversification and policies is also investigated by Weltin et al. [6]. Their work covers different regions in Europe and deals with both the first and the second pillar of the CAP. While the first pillar is mainly considered a mere integration of the farm income, the second pillar support implies a contractual relationship between farmers 
and institutions and the ability to develop a multi-year business plan. Weltin et al. [6] also present a no-CAP scenario where farms either quit the business or increase the rate of diversification at a different pace according to type of farms and farmers' age. In these cases, diversification, as well as pluri-activity, become a sort of last step before the unavoidable abandonment of the business, especially for small family farms in constant crisis due to the long-term declining trend of agricultural incomes or the proposition of a new model as a reaction to the highly specialization process of industrialized agriculture [25,26]. If pluri-activity and part-time farming depend mostly on the socio-economic conditions of the external environment, which is key for moving part of the family labor force out of the sector, diversification can happen for a variety of reasons that can go from nonentrepreneurial reasons, such as the residential use of farms or self-consumption, to proper entrepreneurial skills, such as educational farms, tourism, or therapeutic uses, which, in turn, also require specific skills that enlarge labor opportunity in rural areas.

\subsection{The Factors of Diversification in Peri-Urban Agriculture}

In recent years, an increasing number of studies has focused the attention on periurban farming and on its key productive, environmental, social, and landscape features. Scholars are giving particular attention to the multifunctional role of this type of agriculture, which is often characterized by diversification processes that assume specific features because of the rural-urban reciprocal influences and of the demand for new goods and services required of farmers by city dwellers $[15,17,27,28]$.

It can be argued that the characteristics of peri-urban agriculture and, consequently, of its main multifunctionality and diversification pathways, are often the results of both "external factors" (e.g., the interaction of this type of farming with the surrounded urban contexts) and "internal factors" (e.g., the structural and economic features of peri-urban farms, as well as the socio-economic profile of farmers).

With regards to the "external factors", the access to farmland has been recognized as one of the keys limiting factors of this type of agriculture. In peri-urban contexts, the high profitability of land uses alternative to farming, such as industry and housing, brings about the planning challenge of managing in an effective way a broad range of interests and competition for land [16]. In the European context, the uncontrolled urban sprawls and the consequent decreasing of the overall environmental quality of peri-urban landscapes is particularly relevant in Mediterranean cities, often characterized by inadequate planning instruments and poor environmental regulations [29,30].

Access to land may also affect in different ways the adoption of alternative business models and, more in general, the diversification processes of peri-urban farms [3]. As shown by Pölling et al. [31], who investigated farming patterns in German Ruhr Metropolis, farmland losses and increased competition for the remaining land negatively affect diversification since, to be successful, diversified farms require certain amount of farmland.

If the access to land is often recognized as an important limiting factor, the proximity of peri-urban farms to the city may have a positive influence on farm competitiveness, especially thanks to a more effective market valorization of products in local markets. Indeed, a specific feature of peri-urban farming that has been increasingly investigated is the role of alternative food networks (i.e., direct sales, box schemes, farmers' markets, etc.) [32]. Although such networks have the potential to shorten the distance between the consumer and the farmer, similarly to the rural context, also in peri-urban areas such initiatives require active farmer involvement and key stakeholder participation, resulting in mutual commitment [33].

To date there is no solid evidence to what extent the proximity to cities affects the farmers' decision-making on diversification choices. As an example, on the basis of the results of a survey conducted amongst farms in Eastern Germany, Lange et al. [22] argue that diversification is more associated with rurality and touristic development rather than with the proximity to urban consumer markets; the authors show that while rural attractiveness 
positively affects the farmers' decision-making to diversify activities, the degree of urbanization encourages farm holders to continue farming activity. Pölling and Mergenthaler [34] investigated the factors influencing the decision to diversify peri-urban farms in Germany by applying a binary logit model and reached different conclusions: proximity to cities can be successfully exploited by farmers when applying consumer-oriented "deepening" or "broadening" strategies, such as direct sale or other short supply chains, tourism services, and care farming.

This literature refers to external factors affecting diversification of peri-urban farming not only by considering the physical assets available (land, water, roads, and other infrastructures) but also the presence of institutional and social networks (local institutions, NGOs, civil society organizations, consumers' groups) as important drivers that may affect farmers' behavior [3,35]. In this regard, as shown in the exploratory research by Vecchio et al. [36], innovative milieus may play a fundamental role in boosting the uptake of sustainable innovations among young farms working in urban and peri-urban contexts.

With regards to the "internal factors", some studies have investigated the diversification strategies of peri-urban farms in relation to their structural features [37-39], as well as to the socio-economic profile and entrepreneurship of farmers [3,23]. To date, only a very limited number of studies have investigated the production factors and the income dynamics of peri-urban farms in relation to diversification strategies [40-42].

The most recent analysis of diversification patterns of peri-urban farming in Italy show that diversification is becoming a specific business strategy developed by the most structured and market-oriented peri-urban farms, with an increasing number of farmers that are adopting innovative solutions to provide a broad variety of social and economic services to the urban population [3,39].

By analyzing the strategies of farms located in the immediate border to the city of Gothenburg, in Sweden, Wastfelt and Zhang [40] show that farmers adapt and form competitive advantage by controlling labor costs. This control is mainly carried out by allowing the consumers to do the harvesting work themselves, getting rid of middleman in sales and limiting the time spent on distribution.

The dynamics and variability in income of commercial farms operating in metropolitan areas of Poland were analyzed by Wojewodzic et al. [41] by using FADN data. The authors compared the performance of farms in outer and inner metropolitan zones, and results showed that in the inner metropolitan area zones, farmers have a considerably higher income from one unit of own work. FADN data were also used by Wojewodzic and Sroka [42] to explore the directions of changes in production factors of commercial farms operating in six selected Polish metropolitan areas. This study shows that in the inner zone there is a high percentage of farms reducing land, labor, and capital resources due to the existing barriers to their further development, and this results in a search for alternative development paths, namely, diversification and the development of non-agricultural services.

Finally, recent evidence has been collected on diversification patterns and entrepreneurship of peri-urban farming in Japan. Yoshida et al. [23] demonstrate the existence in periurban areas of advanced diversified farms characterized by entrepreneurship and skilled farm management but also revealed that advanced diversification has a positive impact on both social and economic performance of farms.

\section{Conceptual Framework}

The main objective of this work is to identify and assess the key factors influencing on-farm income diversification in Italian peri-urban agriculture. In greater details, we aimed at testing the two mentioned hypotheses.

Hypothesis 1 (H1). Peri-urbanity is a key feature influencing the combination and weight of push and pull factors driving on-farm diversification.

Hypothesis 2 (H2). Peri-urbanity may change the relations and the intensity of both pull and push factors. 
To achieve this objective, a conceptual framework was developed (Figure 1) to show the expected relations amongst factors influencing farm incomes and revenues. This conceptual framework was also used as a basis on which the structural equation model was developed to assess the strength/intensity of the identified relationships (see Section 4 below). The framework is largely based on the FADN balance sheets, and the relationships amongst the budget items follow the accounting principles used by the International Accounting Standards Board (IASB) in financial statements [43,44].

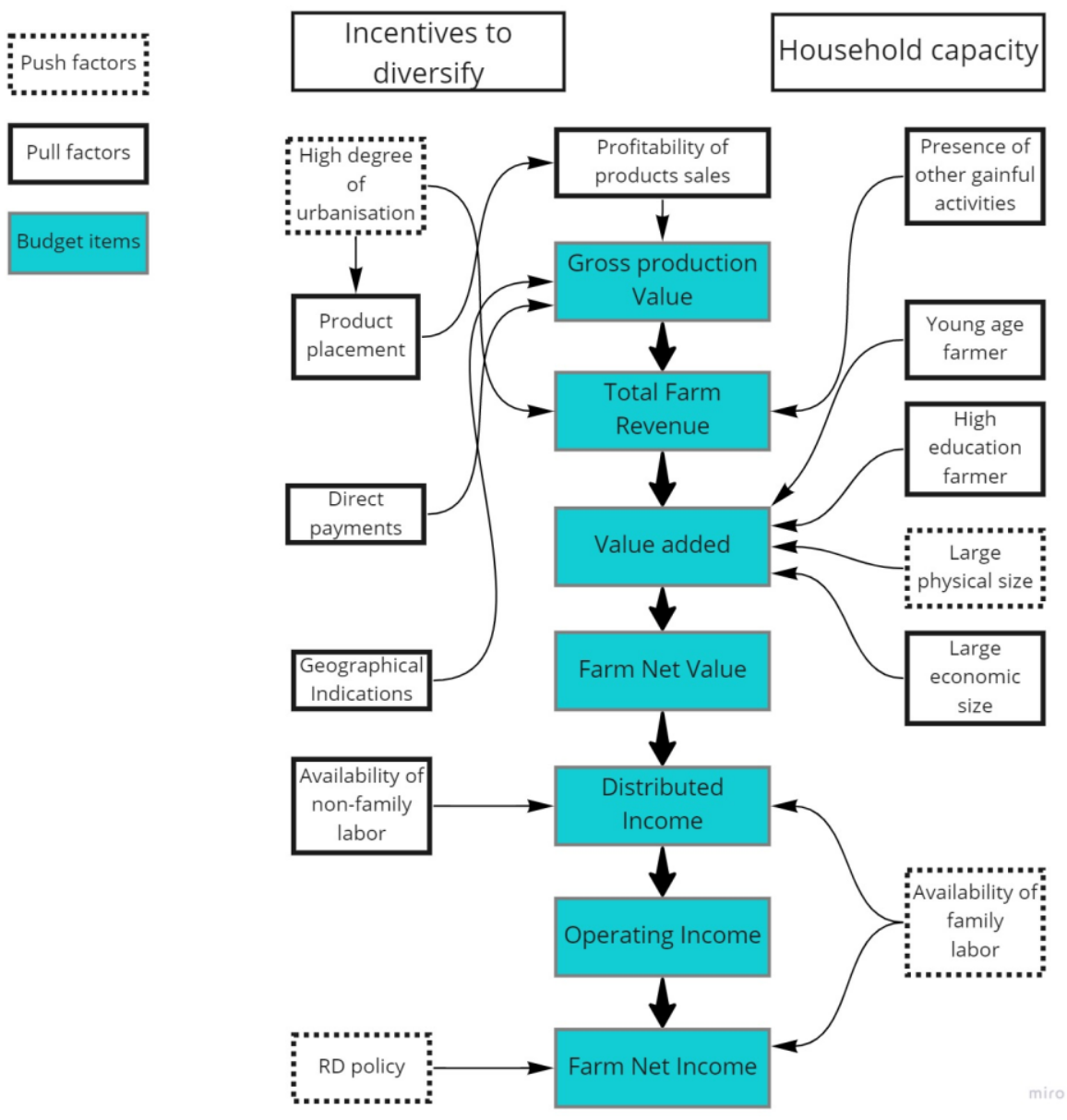

Figure 1. Conceptual framework.

Using the FADN budget sheet as a starting point, the identification and classification of push and pull factors influencing on-farm income diversification was carried out by using the recent literature on the topic (see Section 2.2 above). In particular, we followed the approach proposed by Reardon et al. [10], who distinguished the factors determining income diversification in two groups: "incentives to diversify" and "household capacity". In each of the two groups, the factors were further divided into push and pull factors. Most factors were categorized as pull factors, assuming that they represent diversification opportunities by allowing farmers to achieve further economic benefits by expanding their range of activities. Conversely, factors such as degree of urbanization and physical size of farms were interpreted as factors that may "push" farms to diversify in order to increase their resilience and to better manage economic risks. It must be highlighted that although such categorization was mainly based on the literature, some factors could act either as push or pull factors according to the specific structural features of farms, as well as according to the socio-economic context where they operate [3].

It can be observed in Figure 1 that each factor was associated to the budget item it was expected to influence the most. In some cases, a single factor was considered to influence more than one budget item. This is the case for the availability of family labor, which was 
expected to influence both distributed income (DI) and farm net income (FNI), or the degree of urbanization, which was expected to influence directly total farm revenue (TFR) and, indirectly, gross production value (GPV) via product placement and profitability of product sales. In this case, it was assumed that in urban areas, it is easier to commercialize agricultural products, and this would affect the profitability of product sales and, therefore, the TFR.

When looking at the direct relationships between factors and other budget items, some pull factors, such as direct payments and geographical indications, were considered as positively influencing GPV, as well as the presence of other gainful activities, a factor that is supposed to positively influence TFR. Indeed, it can be assumed that all these factors usually lead to higher on-farm returns.

With regards to policy support, direct payments were classified as a pull factor, since such payments are mainly conceived as an income support $[45,46]$ with direct and positive effects on gross production value and may also have an income stabilizing effect [47]. On the contrary, rural development policies are structured as a voluntary support, which is particularly relevant for small and marginal farms to manage risk and to cope with shocks [14]; for this reason, such policies were considered a push factor.

As for other factors, we assumed that large physical size (measured in hectares of utilized agricultural area) would positively affect the farmers' willingness to diversify, as also demonstrated in previous studies [9,22,39]. Similarly, a positive relation with income diversification was also assumed for the economic size of farms (measured in terms of standard output) since the economic size is likely to be correlated with a higher income, also by providing easier access to credit [48].

Furthermore, the low age of farmers was included among the pull factors for diversification, supported by previous research that demonstrated that younger farmers are more likely to engage in diversification (especially broadening) activities [49-51]. Similarly, as demonstrated in several studies [51,52], the level of education is often positively correlated with the willingness of farmers to diversify.

Finally, as highlighted above, the availability of family labor was considered to positively influence farm income: this is particularly true for other gainful activities since, in many cases, deepening and broadening activities are also adopted to employ family members on the farm $[53,54]$.

\section{Materials and Methods}

\subsection{Data}

All the data used for the analysis come from the Italian Farm Accountancy Data Network $^{1}$ (FADN), concerning the 2008, 2013, and 2018 accounting years. The selected years allow for exploration of the evolution of the different factors over a decade covering different socio-economic and policy conditions (e.g., the decade 2008-2018 involved two EU common agricultural policy (CAP) programming periods, 2007-2014 and 2014-2020). The FADN sample represents the national agriculture in a statistically reliable way as it considers the farm's production system and economic size. In particular, the FADN monitors farms' income and business activities. It is also an informative source for understanding the impact of the measures taken under the CAP. FADN data, in accordance with Council Regulation (EC) n. 1217/2009 only cover "commercial farms", namely, those farms exceeding a minimum economic size defined at member state level. It is worth highlighting that the relatively low threshold established for Italy for "commercial farms" (8000 euros) allowed us to include in our analysis a consistent proportion of small farms.

The final dataset included 4896 farms (1789 in 2008, 1595 in 2013, and 1512 in 2018). Farms were classified as rural or peri-urban according to their localization, based on the classification of rural areas of the National Strategic Plan for Rural Development in both 2007-2013 and 2014-2020 programming periods [55,56]. This classification identified four typologies of areas: (a) urban and peri-urban areas; (b) areas with intensified and specialized agriculture; (c) intermediate areas; (d) less developed areas. 
More specifically, we selected all FADN farms localized in urban and peri-urban areas (a) corresponding to 1341 units and, for rural areas (areas b, c, and d), we selected the 3555 farms localized in the municipalities directly bordering with the municipalities included in areas (a) urban and peri-urban. This choice was motivated by the need of identifying and analyzing the key factors characterizing the conditions of peri-urbanity by comparing two groups of farms that, due to the rural-urban continuum [57], have rather similar features in terms of specialization, socio-economic, and environmental conditions.

In the FADN, farms are selected at random from the field of observation. The sample design is carried out with the rotating panel technique, and a share of the sample is periodically renewed (every $4-5$ years, with annual renewal of $20-25 \%$ of the survey units). However, this could lead to a certain discontinuity in the observations [58].

In terms of structural features, the two groups of farms (that we defined as peri-urban and rural) do not show significant differences. More than half of the farms are smaller than 15 hectares. However, peri-urban farms show a higher percentage of the unspecialized type of farming (mixed cropping). When looking at the structural changes observed during the period under study, for both groups there was a reduction of the number of small farms (UAA $<5$ ha) and an increase of farms with an agricultural area comprised between 5 and 15 hectares. Rural farms showed an increase in the number of farms with an area comprised between 15 and 40 hectares and an increase of farms run by women. Over $50 \%$ of the farmers were aged between 40 and 65 . Although in terms of education there were no appreciable differences between the two groups, peri-urban farms show a slight predominance toward graduate farmers.

The explanatory variables related to costs and revenues of the FADN dataset used in the empirical analysis are reported in Table 1, while Table 2 reports all the variables used as proxies for all the identified factors (incentives to diversify/household capacity and push/pull).

Table 1. FADN budget items and related variables with means and standard deviations between brackets.

\begin{tabular}{|c|c|c|c|c|c|}
\hline $\begin{array}{l}\text { Budget } \\
\text { Items }\end{array}$ & Variable & Description & 2008 & 2013 & 2018 \\
\hline \multirow{8}{*}{ Costs } & OC & Operating Costs $(€)$ & $83,879.20( \pm 487,396.67)$ & $90,600.27( \pm 281,808.02)$ & $96,804.99( \pm 574,239.88)$ \\
\hline & $\mathrm{EF}$ & External Factors $(€)$ & $62,692.93( \pm 376,618.71)$ & $70,977.73( \pm 246,576.60)$ & $71,135.68( \pm 464,463.27)$ \\
\hline & TPS & Third Party Services $(€)$ & $6469.18( \pm 55,536.21)$ & $6922.16( \pm 29,793.78)$ & $9586.26( \pm 47,931.93)$ \\
\hline & FPR & Farm Passive Rentals $(€)$ & $3735.39( \pm 52,239.12)$ & $2836.10( \pm 7376.68)$ & $3423.94( \pm 12,854.57)$ \\
\hline & OSC & Other Specific Costs $(€)$ & $14,717.09( \pm 95,540.24)$ & $12,700.38( \pm 40,702.29)$ & $16,156.79( \pm 106,458.59)$ \\
\hline & Dep & Depreciation & $9791.67( \pm 19,400.37)$ & $10,214.25( \pm 21,529.84)$ & $9917.82( \pm 23,925.07)$ \\
\hline & MYC & Multi-Year Costs $(€)$ & $10,069.16( \pm 19,960.21)$ & $10,610.48( \pm 22,244.12)$ & $10,153.63( \pm 24,669.99)$ \\
\hline & $\mathrm{RP}$ & Rent Paid $(€)$ & $5181.79( \pm 36,715.15)$ & $5434.93( \pm 20,341.15)$ & $5154.05( \pm 17,559.07)$ \\
\hline \multirow{7}{*}{ Revenues } & VA & Value Added (€) & $98,216.39( \pm 326,927.74)$ & $102,458.73( \pm 254,358.90)$ & $109,396.22( \pm 429,407.62)$ \\
\hline & FNV & Farm Net Value $(€)$ & $88,147.22( \pm 320,589.66)$ & $91,848.25( \pm 244,902.39)$ & $99,242.59( \pm 418,482.25)$ \\
\hline & TFR & Total Farm Revenues $(€)$ & $177,457.87( \pm 709,981.15)$ & $190,587.40( \pm 487,360.69)$ & $204,354.57( \pm 962,380.74)$ \\
\hline & Dis_I & Distributed Incomes $(€)$ & $28,618.19( \pm 161,224.48)$ & $28,935.11( \pm 81,405.20)$ & $27,905.63( \pm 100,683.42)$ \\
\hline & $\mathrm{OI}$ & Operating Income $(€)$ & $59,529.04( \pm 188,953.48)$ & $62,913.14( \pm 182,146.87)$ & $71,336.96( \pm 341,254.85)$ \\
\hline & ECM & $\begin{array}{c}\text { Extra-Characteristic } \\
\text { Management }(€)\end{array}$ & $521.51( \pm 20,143.69)$ & $30.40( \pm 24,420.10)$ & $5397.43( \pm 38,747.362)$ \\
\hline & FNI & Farm Net Income $(€)$ & $60,050.55( \pm 187,159.54)$ & $62,943.53( \pm 181,372.17)$ & $76,734.38( \pm 354,637.32)$ \\
\hline
\end{tabular}


Table 2. Push/pull factors and related variables with means and standard deviations between brackets.

\begin{tabular}{|c|c|c|c|c|c|c|}
\hline Factor & Variable & Description & Type of Factor & 2008 & 2013 & 2018 \\
\hline \multirow{2}{*}{ Degree of urbanization } & DUM & Degree of Urbanization Municipality & & $2( \pm 0.71)$ & $2.03( \pm 0.70)$ & $1.98( \pm 0.72)$ \\
\hline & DRM (SC) & Degree of Rurality Municipality & Push & $0.50( \pm 0.19)$ & $0.49( \pm 0.20)$ & $0.48( \pm 0.20)$ \\
\hline \multirow{2}{*}{ RD policy } & Ot_Sub_N_EU & Other Subsidies non EU $(€)$ & /Incentives to diversify & $1077.37( \pm 6021.05)$ & $2163.25( \pm 8352.82)$ & $4923.52( \pm 17076.97)$ \\
\hline & Sub_Ca & Subsidies in Capital account $(€)$ & & $21.18( \pm 265.04)$ & $1384.18( \pm 11,623.87)$ & $373.26( \pm 8038.34)$ \\
\hline \multirow{10}{*}{ Product placement } & Ret & Retailer $(\%)$ & \multirow{13}{*}{$\begin{array}{c}\text { Pull } \\
\text { /Incentives to diversify }\end{array}$} & $2.32( \pm 13.03)$ & $3.32( \pm 16.09)$ & $2.62( \pm 13.90)$ \\
\hline & SC & Self-Consumption (\%) & & $7.87( \pm 23.55)$ & $13.74( \pm 32.44)$ & $16.59( \pm 34.94)$ \\
\hline & Ind & Industry (\%) & & $2.17( \pm 12.66)$ & $5.41( \pm 18.98)$ & $6.53( \pm 20.98)$ \\
\hline & FRet & Farm Retail (\%) & & $2.62( \pm 13.55)$ & $3.69( \pm 15.60)$ & $3.51( \pm 15.62)$ \\
\hline & WE & Wholesale-Export (\%) & & $78.01( \pm 37.94)$ & $55.29( \pm 45.98)$ & $31.01( \pm 42.71)$ \\
\hline & AgriT & Agritourism (\%) & & $0.13( \pm 2.88)$ & $0.47( \pm 5.86)$ & $0.82( \pm 7.11)$ \\
\hline & Ot_S & Other Subject (\%) & & $0.07( \pm 2.07)$ & $4.33( \pm 19.56)$ & $15.78( \pm 35.49)$ \\
\hline & Coop_R & Cooperative Regular VAT (\%) & & $3.68( \pm 16.81)$ & $3.16( \pm 15.85)$ & $3.76( \pm 17.59)$ \\
\hline & Coop_S & Cooperative Special VAT (\%) & & $0.616( \pm 6.98)$ & $1.94( \pm 12.41)$ & $8.33( \pm 26.26)$ \\
\hline & GPVDS & GPV Direct Sale $(€)$ & & $3828.70( \pm 47,600.68)$ & $7000.15( \pm 59,308.76)$ & $5505.37( \pm 38,631.37)$ \\
\hline Policy support & DP (Pil I) & Direct Payments (Pillar I) $(€)$ & & $11,129.06( \pm 27,535.70)$ & $14,445.21( \pm 65,190.94)$ & $11,839.88(27,423.20)$ \\
\hline $\begin{array}{l}\text { *Geographical } \\
\text { indications }\end{array}$ & QC & Quality Certification (Dummy, Y/N)) & & $0.09( \pm 0.28)$ & $0.15( \pm 0.36)$ & $0.21( \pm 0.41)$ \\
\hline Labor availability & WUPL & Work Unit of Paid Labor & & $1.13( \pm 4.53)$ & $1.05( \pm 3.70)$ & $0.98( \pm 4.59)$ \\
\hline Farm size & UAA & UAA (ha) & Push & $32.09( \pm 68.42)$ & $34.33( \pm 74.38)$ & $31.15( \pm 59.91)$ \\
\hline \multirow{3}{*}{$\begin{array}{l}\text { Profitability of product } \\
\text { sales }\end{array}$} & GPVPP & GPV Processed Product $(€)$ & \multirow{13}{*}{$\begin{array}{c}\text { Pull } \\
\text { /Household capacity }\end{array}$} & $11,979.77( \pm 92,664.74)$ & $12,178.05( \pm 86,924.18)$ & $17,544.22( \pm 323,898.23)$ \\
\hline & GPVC & GPV Crops $(€)$ & & $103,163.71( \pm 521,687.32)$ & $93,424.06( \pm 267,601.89)$ & $95,695.44( \pm 374,823.09)$ \\
\hline & GPVQ & GPV Quality $(€)$ & & $2725.75( \pm 33,742.95)$ & $3178.25( \pm 42,094.50)$ & $28,720.08( \pm 787,653.98)$ \\
\hline \multirow{7}{*}{ Other gainful activities } & OGA & Other Gainful Activities revenues $(€)$ & & $2927.24( \pm 25,255.63)$ & $6089.53( \pm 46,601.87)$ & $12,076.66( \pm 77,111.05)$ \\
\hline & GPVDS & GPV Direct Sale $(€)$ & & $3828.70( \pm 47,600.68)$ & $7000.15( \pm 59,308.76)$ & $5505.37( \pm 38,631.37)$ \\
\hline & AgriT_R & Agritourism Revenues $(€)$ & & $984.52( \pm 15,662.85)$ & $1391.76( \pm 19,919.49)$ & $3713.22( \pm 33,427.57)$ \\
\hline & $\mathrm{AR}$ & Active Rent $(€)$ & & $57.98( \pm 1029.57)$ & $240.17( \pm 3290.14)$ & $683.64( \pm 17,360.77)$ \\
\hline & Deep_Ac & Deepening Activities $(€)$ & & $1618.80( \pm 19,184.57)$ & $2373.19( \pm 19,777.07)$ & $3557.45( \pm 25,926.41)$ \\
\hline & Ot_BRO_Ac & Other Broadening Activities $(€)$ & & $112.27( \pm 2671.68)$ & $60.48( \pm 1103.93)$ & $270.91( \pm 7045.46)$ \\
\hline & $\overline{\mathrm{HMCL}}$ & Hire of Machinery (Contract Labor) $(€)$ & & $157.54( \pm 2276.15)$ & $391.43( \pm 3509.28)$ & $517.29( \pm 4907.73)$ \\
\hline Age & Age & Age (years) & & $56.72( \pm 14.04)$ & $56.05( \pm 13.58)$ & $56.70( \pm 13.79)$ \\
\hline *Education & EQD & Educational Qualification Description & & $2.93( \pm 1.67)$ & $3.47( \pm 1.45)$ & $3.91( \pm 1.46)$ \\
\hline Economic size & ESG & Economic Size Group & & $3.20( \pm 1.32)$ & $2.70( \pm 1.37)$ & $2.76( \pm 1.28)$ \\
\hline
\end{tabular}

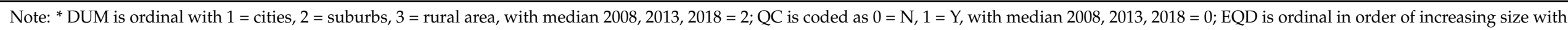
eight categories, with median 2008, $2013=3,2018=4$; ESG is ordinal in order of increasing size with five categories, with median 2008, $2013,2018=3$. 


\subsection{The Structural Equation Model}

In order to disentangle the complex relationships hypothesized with the conceptual model depicted in Figure 1, a measured variable path analysis-based structural equation modeling (MVPA-based SEM) [19,20] was applied to the Italian FADN selected data. Although SEM models are not novel either in econometrical $[59,60]$ or even in ecological problems [61,62], to our knowledge, this is the first attempt to model FADN data through a SEM approach. Past research on farms/rural income diversifications issues proposed modeling approaches based on classic regression-led strategies, such as Poisson regression [63], stochastic linearized model [43], binary logit models [64], multiple regressions [65], even with dummies [66], and simple time variant interpolations [41]. Otherwise, classification strategies were used by means of factor and cluster analysis $[6,24,32]$ or even with indexes segmentations [22]. From a SEM perspective, a path model analysis is a multiequation data analytical approach, (mostly linear but not limited to) that permits researchers to verify multiple connected hypotheses among measured and/or latent variables simultaneously $[19,20]$. Hence, the main difference between path and regression models is that the former is able to statistically test for theory-driven causality among multiple independent variables on one or more dependent variables, and even among those dependent variables themselves, including several regression equations [67]. This approach sounds much more flexible than multiple regressions, especially when complex causality among dependent and independent variables are being hypothesized. MVPA-based SEM applies covariance algebra or path tracing rules by Wright's [68], where correlations/(co)variances of observed variables can be decomposed into direct, indirect, and non-structural components and, therefore, include mediation analysis as well [69]. Essentially, SEM models belong to the family of the covariance structure models [67] and, thus, permit us to understand why and how different variables covary each other by accepting or rejecting hypotheses on their multiple relations while providing also completely standardized solutions.

In order to briefly understand how SEM models work, we take the path model represented in Figure 2 that retraces an example of some connection hypothesized in the conceptual model of Figure 1.

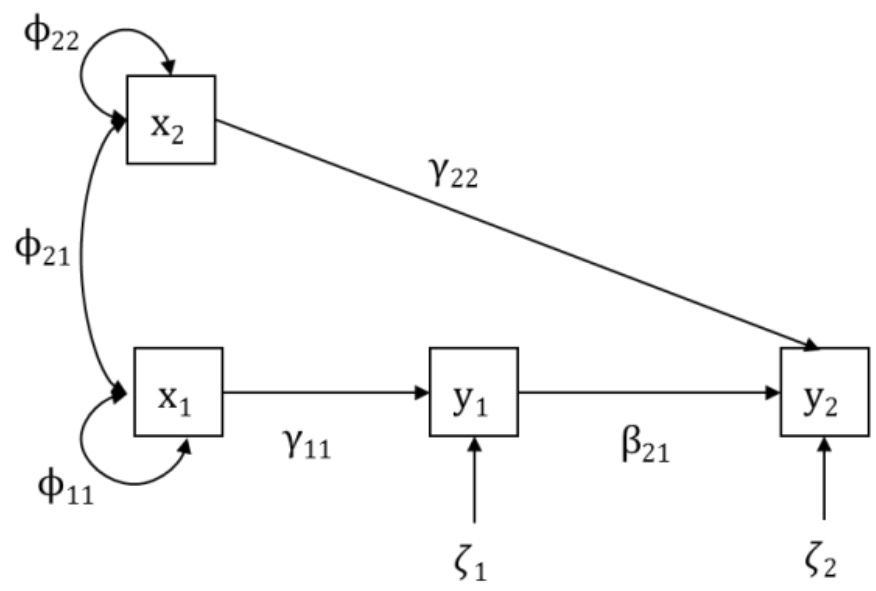

Figure 2. Path model with four measured variables.

The path model in Figure 2 can be written in the following system of structural equations:

$$
\begin{gathered}
\mathrm{y}_{1}=\gamma_{11 \times 1}+\zeta_{1} \\
\mathrm{y}_{2}=\gamma_{22 \times 2}+\beta_{21} \mathrm{y}_{1}+\zeta_{2}
\end{gathered}
$$

or more generally in matrix equation:

$$
\mathrm{y}=\mathrm{By}+\Gamma \mathrm{x}+\zeta
$$


where $\mathrm{y}, \mathrm{x}$, and $\zeta$ are respectively the vectors of endogenous $(p \times 1)$, exogenous $(q \times 1)$, errors $(p \times 1)$ variables, while $\mathbf{B}$ and $\Gamma$ are respectively the $m \times m$ and $m \times n$ coefficients matrices. The basic assumptions are that the errors $\zeta$ are uncorrelated to each other (i.e., the $\Psi$ errors matrix is diagonal) and with the exogenous variables.

Simplifying the structural process, the application of Wright's tracing rules of observed variances and covariances decomposition of (any) two variables into structural parameters consists of: (a) when moving from one variable to another, a researcher can go forward or backward and passing through a variable just once; (b) should un-analyzed paths (i.e., covariation between two exogenous variables) be present, it is allowed to pass through them only once and from the first variable to the last variable in a route (see also 70). Hence, by following the paths routes in the model of Figure 2 and the relative Equations (1) and (2), the reader can easily compute the relative variances and covariances decomposition of the four observed variables into structural parameters as follows:

$$
\begin{gathered}
\operatorname{var}\left(\mathrm{x}_{1}\right)=\varphi_{11} ; \operatorname{var}\left(\mathrm{x}_{2}\right)=\varphi_{22} ; \operatorname{var}\left(\mathrm{y}_{1}\right)=\gamma_{21}{ }^{2} \varphi_{11}+\psi_{11} ; \operatorname{var}\left(\mathrm{y}_{2}\right)=\beta_{21}{ }^{2}\left(\gamma_{22}{ }^{2} \varphi_{22}+\psi_{11}\right)+\gamma_{22}{ }^{2} \varphi_{22}+\psi_{22} \\
\operatorname{cov}\left(\mathrm{y}_{1}, \mathrm{y}_{2}\right)=\beta_{21}\left(\gamma_{22}{ }^{2} \varphi_{22}+\psi_{11}\right) ; \operatorname{cov}\left(\mathrm{x}_{1}, \mathrm{y}_{1}\right)=\gamma_{11} \varphi_{11} ; \operatorname{cov}\left(\mathrm{x}_{1}, \mathrm{y}_{2}\right)=\beta_{21} \gamma_{11} \varphi_{11} ; \operatorname{cov}\left(\mathrm{x}_{2}, \mathrm{x}_{1}\right)=\varphi_{21} \\
\operatorname{cov}\left(\mathrm{x}_{2}, \mathrm{y}_{2}\right)=\gamma_{22} \varphi_{22}+\varphi_{21} \gamma_{11} \beta_{21} ; \operatorname{cov}\left(\mathrm{x}_{2}, \mathrm{y}_{1}\right)=\varphi_{21} \gamma_{11}
\end{gathered}
$$

As a result, we obtained a new system of 10 equations with 10 known parameters, or pieces of information ${ }^{2}$, that is, the number of variances and the covariances of all the observed variables involved in the model in Figure 2 and eight unknown parameters to be estimated. From the system (4), it should be straightforward how the decomposition process of the covariance algebra is able to reveal the most common direct effects and the novel indirect effects. These latter are the results of the multiplication of the relative path parameters: the indirect effect of $x_{1}$ on $y_{2}$ is equal to $\gamma_{11} \beta_{21}$, for instance. The strength of path analysis is that a model like the one in Figure 2 allows $\mathrm{y}_{1}$ and $\mathrm{x}_{1}$ to vary (i.e., not holding them constant), respectively, in terms of direct and indirect effect on $\mathrm{y}_{2}$, while $x_{2}$ is directly and simultaneously impacting on $y_{2}$.

From this simple example, the reader can understand how the complexity of the connections may develop and increase and, thus, how the decomposition process might involve many parameters simultaneously by making use of all the available information: the variances and covariances matrix $\sum$ of the observed variables involved in the model. Generally, if every known parameter can be re-written as a function of the unknown modelimplied parameters, the model is identified [19] (p. 89) and can be reasonably estimated. More formally, $\sum=\sum(\theta)$ [20] (p. 85), where $\sum(\theta)$ is the model-implied matrix of variances and covariances re-written as function of one or more model parameters. If the model is identified, the $\sum$ matrix is substituted by a matrix $S$ taken from a random sample of a population of interest, and the process of estimation involves a function that minimizes the discrepancy $(S-\hat{\theta})$ between the $S$ and an estimation of $\Sigma(\theta)=\hat{\theta}$. Currently, SEM provides many functions of estimation that depend on both the nature of the variables and their violation of multi-normality assumption. Here, due to the presence of many quantitative variables that significantly deviate from multi-normality (data not shown but can be requested from the authors) we used the robust maximum likelihood (RML) [71] correction with an asymptotic covariance matrix, which is the most common method of estimation in this situation [72].

In addition to the significant path solutions and the relative r-squares, SEM models output provides several indices to evaluate the fit of the data to the hypothesized model. These fit indices can be classified into three categories, since they provide a specific model evaluation: absolute fit (to evaluate the overall discrepancy (i.e., residuals evaluation) between observed and model-implied (co)variances), parsimonious fit (to evaluate the overall discrepancy while taking into account the model simplicity and useful parameters), and incremental fit (to evaluate a model's absolute or parsimonious fit relative to a null baseline model). To accept a good model, most of the fit indices need to satisfy the recommended cut-off criteria. The general SEM model's fit was assessed using: the Satorra-Bentler (S-B) correction for non-normality scaled chi-square test and the goodness-of-fit index (GFI) as 
absolute goodness-of-fit indexes; the root mean square error of approximation (RMSEA) as parsimonious fit index; and the comparative fit index (CFI) and the non-normed fit index (NNFI) as incremental fit indices. Most of the SEM scientific community [73-76] suggests cut-off values of the aforementioned fit indexes: (a) low and not significant chisquare values are symptoms of good fit even though they are often found significant due to the well-known limitations of this index, which is sensible to sample size. However, the chi-square magnitude is always reported as first indication of discrepancy; (b) values of RMSEA equal to or less than 0.05 are considered a good fit, in the range between 0.05 to 0.08 marginal, and greater than 0.10 a poor fit; (c) GFI is similar to the coefficient of determination used in linear regression, but here applied to the entire model, and it reveals the amount of variance and covariance explained by the model [19]; (d) values greater than 0.90 for CFI, and NNFI are considered adequate for a good model fit, although values approaching and over 0.95 are preferred. Furthermore, in order to evaluate if the effective sample sizes are able to detect potential misspecifications in reference to a discrepancy index in the path-models, a statistical power plot analysis was performed over the RMSEA indexes found in the estimated models. By doing so, the R-based script for the function "semPower.powerPlot.byN" [77] was applied. Finally, a bootstrapping analysis on the asymptotic covariance matrix was performed to test for the stability estimations, taking into account the sampling variability.

The SEM analyses were conducted using the software LISREL v9.30 for windows [78].

\section{Results and Discussion}

The conceptual model was composed of 47 observed variables for 2256 pieces of information (i.e., observed variances and covariances), while the total number of modelimplied structural parameters were 1849 (with 47 direct effects and 192 indirect effects). As a consequence, the model was over-identified with degrees of freedom that ranged from 407 to $405^{3}$ and could be checked for being accepted or falsified. On the whole, the models provided satisfactory fit indices approaching the recommended cut-off criteria (see Table 3 where "N" stands for the effective sample size after a listwise deletion: all records are considered without missing values). The Satorra-Bentler $\chi^{2}\left(\mathrm{SB}-\chi^{2}\right)$ is commonly expected to be significant with a global explained variance and covariance around $80 \%$ (see GFI values). This fair value has occurred because of the presence of many not significant paths. The chi-square difference absolute values between peri-urban and rural models by each year revealed that less discrepancy was found in 2018:

$$
\begin{aligned}
& { }_{2008} \Delta \chi^{2} \text { (a vs. d) }=\mid \chi^{2} \text { (a) }-\chi^{2}(\mathrm{~d})|=| 704.61-479.32 \mid=225.29 \\
& 2013 \Delta \chi^{2} \text { (b vs. e) }=\mid \chi^{2} \text { (b) }-\chi^{2} \text { (e) }|=| 419.46-668.51 \mid=249.05 \\
& { }_{2018} \Delta \chi^{2} \text { (c vs. f) }=\mid \chi^{2} \text { (c) }-\chi^{2} \text { (f) }|=| 440.18-368.60 \mid=71.58
\end{aligned}
$$

The incremental fit indexes CFI and NNFI were found particularly good, and this means that the hypothesized model relations, in comparison to a baseline model named "null model" (where the covariations are almost close to zero). are very relevant for all models. The first parsimonious fit index AIC showed the less values for the rural model in 2018 and not-so-distant in peri-urban models in 2013 and 2018. This result, together with the second parsimonious index RMSEA, which was found very good (i.e., values under 0.05 and close-range values for the confidence intervals; $\mathrm{CI}$ ), evaluated the overall model complexity in relation to relative useful contribution of each hypothesized structural paths [20], meaningfully acceptable. The RMSEA index was found particularly fine for peri-urban models in 2013 and 2018 and rural models in 2008 and 2018. The fit indexes of the bootstrap samples (i.e., 1000 and 3000 were, respectively, considered for the peri-urban and rural models, both with respect to the original sample sizes and the general minimum of 1000; [79]) were found essentially equal to, or even better than (in only peri-urban, 2008 performed slightly worse), the ones of the empirical samples, and this confirms a certain stability across sampling fluctuation. 
Table 3. Summary of model fit statistics (in italics the bootstrapping results).

\begin{tabular}{ccccccccccc}
\hline Model & $\mathbf{N}$ & $\boldsymbol{S B} \boldsymbol{\chi}^{2}$ & $\boldsymbol{p}$ & $\boldsymbol{d f}$ & GFI & CFI & NNFI & $\begin{array}{c}\text { AIC } \\
\text { RMSEA }\end{array} \begin{array}{c}\text { 90\% CI for } \\
\text { RMSEA }\end{array}$ \\
\hline a. Peri-urban 2008 & 435 & 704.61 & $<0.00$ & 407 & 0.82 & 0.99 & 0.97 & 2146.61 & 0.043 & $(0.038 ; 0.048)$ \\
Bootstrap (1000) & 435 & 759.91 & $<0.00$ & 407 & 0.81 & 0.99 & 0.97 & 2201.91 & 0.047 & $(0.042 ; 0.052)$ \\
b. Peri-urban 2013 & 392 & 419.46 & $<0.00$ & 405 & 0.82 & 1.00 & 1.00 & 1865.46 & 0.010 & $(0.000 ; 0.022)$ \\
Bootstrap (1000) & 392 & 25.30 & 1.00 & 406 & 0.81 & 1.00 & 1.00 & 1469.30 & 0.000 & $(0.000 ; 0.000)$ \\
c. Peri-urban 2018 & 410 & 440.18 & $<0.00$ & 406 & 0.81 & 1.00 & 1.00 & 1884.18 & 0.015 & $(0.000 ; 0.024)$ \\
Bootstrap (1000) & 410 & 408.23 & $<0.00$ & 407 & 0.78 & 1.00 & 1.00 & 1850.23 & 0.003 & $(0.000 ; 0.019)$ \\
d. Rural 2008 & 1176 & 479.32 & $<0.00$ & 405 & 0.79 & 1.00 & 1.00 & 1925.32 & 0.013 & $(0.007 ; 0.017)$ \\
Bootstrap (3000) & 1176 & 453.44 & $<0.00$ & 406 & 0.77 & 1.00 & 1.00 & 1897.44 & 0.010 & $(0.000 ; 0.015)$ \\
e. Rural 2013 & 1036 & 668.51 & $<0.00$ & 406 & 0.84 & 1.00 & 1.00 & 2112.51 & 0.025 & $(0.022 ; 0.029)$ \\
Bootstrap (3000) & 1036 & 239.20 & $<0.00$ & 406 & 0.81 & 1.00 & 1.00 & 1683.20 & 0.000 & $(0.000 ; 0.000)$ \\
f. Rural 2018 & 936 & 368.60 & $<0.00$ & 405 & 0.80 & 1.00 & 1.00 & 1814.60 & 0.000 & $(0.000 ; 0.005)$ \\
Bootstrap (3000) & 936 & 1.69 & 1.00 & 407 & 0.81 & 1.00 & 1.00 & 1443.69 & 0.000 & $(0.000 ; 0.000)$ \\
\hline
\end{tabular}

Figure 3 depicts a plot of the desired statistical power (i.e., the probability of falsifying a model if it is actually wrong and, thus, evaluate the strength of the model specifications) to detect an effect size associated to RMSEA, on an alpha error of 0.05 , ranging from 0.000 to 0.043 (i.e., the RMSEA values of the presented models) over a range of sample sizes.

Power for RMSEA $=0.043$

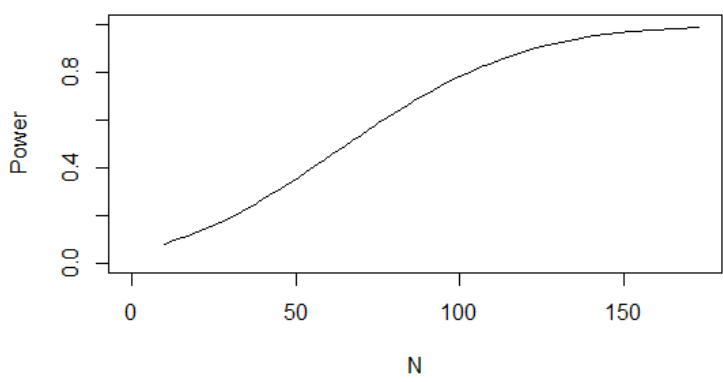

(a) Peri-urban 2008

Power for RMSEA $=0.015$

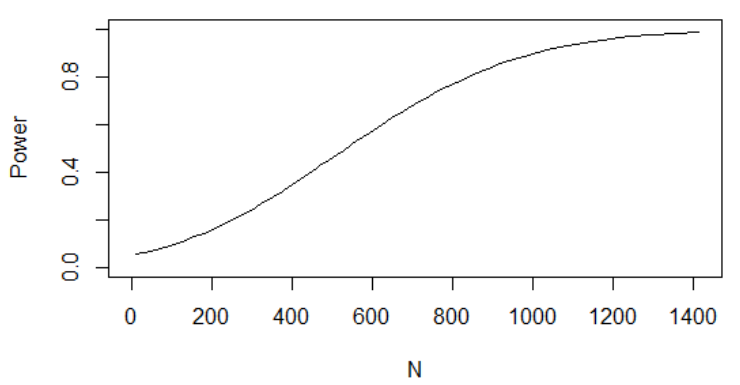

(c) Peri-urban 2018

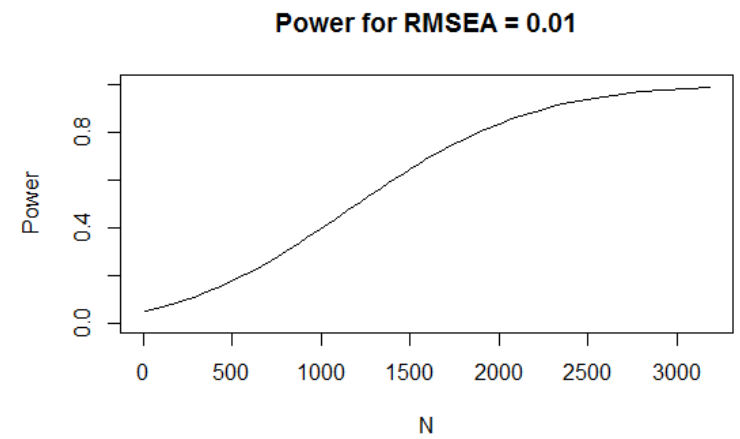

(b) Peri-urban 2013

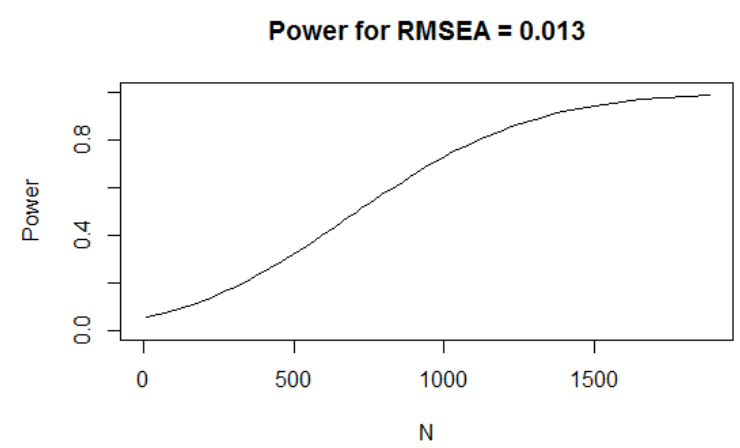

(d) Rural 2008

Figure 3. Cont. 
Power for RMSEA $=0.025$

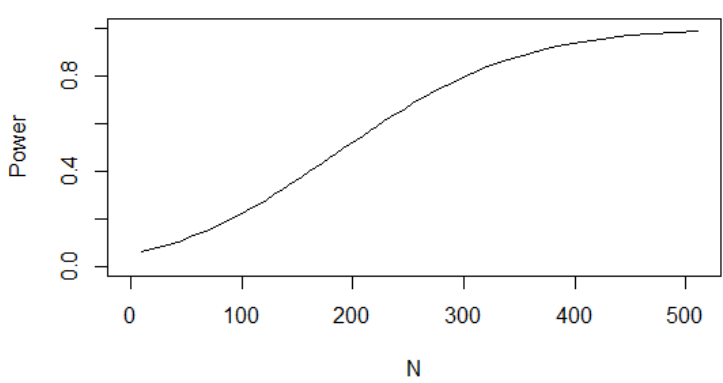

(e) Rural 2013
Power for RMSEA $=0.001$

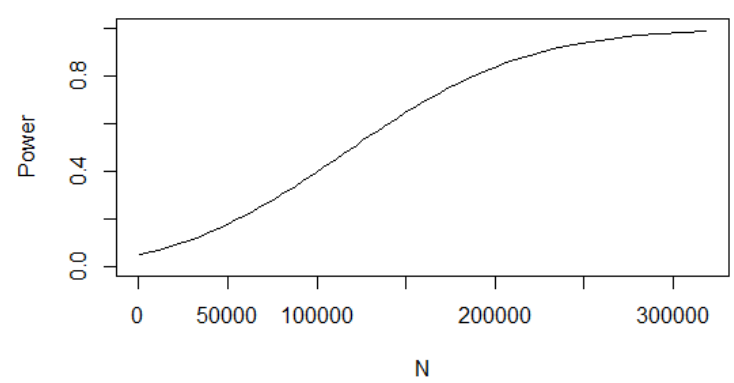

(f) Rural 2018

Figure 3. Power plots as function of sample sizes for RMSEA effects for each model (letters at the bottom between brackets) in Table 3.

Each plot, corresponding to each model RMSEA value and level of complexity (df) presented in Table 3, has to be interpreted as follows [68]: (1) a model with an amount of misspecification corresponding to RMSEA $=0.043$ (i.e., model a in Table 3 ) is rejected with a very high power when $\mathrm{N}$, the sample size, is $>150 ;(2)$ a model with RMSEA $=0.01$ (i.e., model b in Table 3) is rejected with a very high power when the sample size is $>3000$; (3) a model with RMSEA $=0.015$ (i.e., model c in Table 3) is rejected with a very high power when the sample size is $>1300$; (4) a model with RMSEA $=0.013$ (i.e., model d in Table 3) is rejected with a very high power when the sample size is $>1600$; (5) a model with RMSEA $=0.025$ (i.e., model e in Table 3 ) is rejected with a very high power when the sample size is $>500$; (6) a model with RMSEA $=0.01$ (i.e., model $\mathrm{f}$ in Table 4 ) is rejected with a very high power when the sample size is $>300000$. All that means is that the sample sizes associated with model (a) and (e) (i.e., peri-urban 2008 and rural in 2013) are easily able to detect potential misspecifications. In other words, some estimations within these models might be not very tenable, and thus, the specifications would possibly need to be revised because they are affected by that aforementioned discontinuity in the FADN data [48] in those years. This result is even in line with their relative parsimonious indexes AIC and RMSEA that provided the largest values (i.e., smaller values indicate better fit) for model (a) and (e). All the other models required higher sample sizes to detect potential wrong specifications because the residual discrepancy is already low (i.e., RMSEA close to 0.010), and therefore, the estimations are more tenable.

The key results concerning the structural paths obtained through the SEM model are organized on the basis of the conceptual framework presented in Section 3, with a distinction between budget items and push and pull factors, which have been further subdivided into incentives to diversify and household capacity (Table 4). For visualization simplicity's sake, the standardized and the only significant (with t-student value $>|2|$ with $p<0.05$ for one year at least) direct effects are reported (un-standardized solutions, standard errors, $\mathrm{t}$-values can be requested to the authors) together with bootstrap estimates between brackets that confirm the empirical values for the most part ${ }^{4}$. 
Table 4. Standardized solutions of direct relationships of path models by areas and years (ns = not significant; bootstrap standardized estimations between brackets).

\begin{tabular}{|c|c|c|c|c|c|c|c|c|c|c|c|c|}
\hline & & & & \multicolumn{3}{|c|}{ Peri-Urban } & \multicolumn{3}{|c|}{ Rural } & \multicolumn{2}{|c|}{ Factors } & \multirow[t]{2}{*}{ Budget } \\
\hline & & & & 2008 & 2013 & 2018 & 2008 & 2013 & 2018 & Push & Pull & \\
\hline \multirow{14}{*}{ TFR } & \multirow{14}{*}{$<$} & GPVPP & & ns & $0.20(0.40)$ & $\mathrm{ns}$ & $0.11(0.21)$ & ns & ns & & $\checkmark$ & \\
\hline & & GPVC & & $0.56(00.45)$ & $0.63(0.42)$ & $0.08(0.07)$ & 0.25 (ns) & $0.55(0.34)$ & $0.61(0.76)$ & & $\checkmark$ & \\
\hline & & GPVQ & & Ns & ns & $0.96(0.96)$ & ns & ns & $0.38(0.37)$ & & $\checkmark$ & \\
\hline & & DP (Pil I) & & $0.33(0.36)$ & 0.27 (ns) & $0.10(0.10)$ & ns & $0.20(0.29)$ & $0.17(0.12)$ & & $\checkmark$ & \\
\hline & & DUM & & $-0.06(-0.07)$ & ns & ns & ns & ns & ns & $\checkmark$ & & \\
\hline & & DRM (SC) & & $0.07(0.08)$ & ns & ns (0.02) & ns & ns $(-0.02)$ & ns & $\checkmark$ & & \\
\hline & & OGA & & $0.41(0.54)$ & $0.18(0.18)$ & $0.03(0.03)$ & ns (0.03) & $0.14(0.18)$ & ns & & $\checkmark$ & \\
\hline & & Ind & & ns & ns & ns (0.01) & ns & ns & $0.03(0.03)$ & & $\checkmark$ & \\
\hline & & FRet & & ns & $0.02(\mathrm{~ns})$ & ns & ns & ns & ns & & $\checkmark$ & \\
\hline & & WE & & ns & ns & 0.01 (0.ns) & ns & ns & $0.04(0.04)$ & & $\checkmark$ & \\
\hline & & Ot_F & & $-0.05(\mathrm{~ns})$ & ns & ns & ns & ns & ns & & $\checkmark$ & \\
\hline & & Ot_S & & $-0.00(-0.01)$ & ns $(0.22)$ & ns & ns & ns & $-0.04(-0.04)$ & & $\checkmark$ & \\
\hline & & Coop_S & & $0.01(0.02)$ & ns & ns & ns & ns & ns & & $\checkmark$ & \\
\hline & & & $R^{2}$ & 0.75 & 0.69 & 0.99 & 0.19 & 0.45 & 0.72 & & & \\
\hline \multirow{5}{*}{ OGA } & \multirow{5}{*}{$<$} & GPVDS & & $\mathrm{ns}$ & ns & $\mathrm{ns}$ & 0.00 (ns) & $\mathrm{ns}$ & ns & & $\checkmark$ & \\
\hline & & AgriT_R & & $0.89(0.90)$ & $0.11(0.11)$ & $0.65(0.67)$ & $0.41(0.40)$ & $0.69(0.33)$ & $0.43(0.66)$ & & $\checkmark$ & \\
\hline & & Ot_BRO_Ac & & $0.03(0.03)$ & $0.02(0.02)$ & $0.25(0.26)$ & $0.13(0.12)$ & $0.02(0.02)$ & $0.02(0.02)$ & & $\checkmark$ & \\
\hline & & HMCL & & $0.12(0.04)$ & $0.06(\mathrm{~ns})$ & $0.12(0.07)$ & $0.07(0.07)$ & $0.09(0.08)$ & $0.06(0.07)$ & & $\checkmark$ & \\
\hline & & & $R^{2}$ & 0.99 & 0.064 & 0.99 & 0.99 & 0.97 & 0.43 & & & \\
\hline \multirow[t]{6}{*}{ VA } & \multirow[t]{6}{*}{$<$} & OC & & $-0.63(-0.57)$ & $-0.59(-0.84)$ & $-0.61(-0.61)$ & $-0.70(-0.69)$ & $-0.47(-0.58)$ & $-0.67(-0.71)$ & & & $\checkmark$ \\
\hline & & TFR & & $1.22(1.27)$ & $1.13(1.27)$ & $1.59(1.60)$ & $0.77(0.74)$ & $0.98(0.92)$ & $10.19(1.28)$ & & & $\checkmark$ \\
\hline & & EQD & & ns & ns & ns & $0.02(0.02)$ & ns & ns & & & $\checkmark$ \\
\hline & & UAA & & ns & ns & ns & $0.03(0.05)$ & ns & ns & $\checkmark$ & & \\
\hline & & ESG & & ns & ns & $0.03(0.03)$ & $0.02(0.02)$ & ns & ns & & & $\checkmark$ \\
\hline & & & $R^{2}$ & 0.94 & 0.98 & 0.99 & 0.97 & 0.95 & 0.99 & & & \\
\hline \multirow[t]{5}{*}{ OC } & \multirow[t]{5}{*}{$<$} & $\mathrm{EF}$ & & $0.75(0.70)$ & $0.82(0.80)$ & $0.83(0.82)$ & $0.81(0.81)$ & $0.90(0.91)$ & $0.74(0.74)$ & & & $\checkmark$ \\
\hline & & TPS & & $0.14(0.17)$ & $0.19(0.20)$ & $0.04(0.04)$ & $0.12(0.12)$ & $0.07(0.05)$ & $0.15(0.08)$ & & & $\checkmark$ \\
\hline & & FPR & & $0.00(0.00)$ & ns & ns & $0.00(\mathrm{~ns})$ & $0.00(\mathrm{~ns})$ & ns & & & $\checkmark$ \\
\hline & & OSC & & $0.20(0.21)$ & $0.18(0.23)$ & $0.15(0.15)$ & $0.10(0.09)$ & $0.14(0.11)$ & $0.27(0.30)$ & & & $\checkmark$ \\
\hline & & & $R^{2}$ & 0.99 & 0.99 & 0.99 & 0.99 & 0.99 & 0.99 & & & \\
\hline
\end{tabular}


Table 4. Cont.

\begin{tabular}{|c|c|c|c|c|c|c|c|c|c|c|c|c|}
\hline & & & & \multicolumn{3}{|c|}{ Peri-Urban } & \multicolumn{3}{|c|}{ Rural } & \multicolumn{2}{|c|}{ Factors } & \multirow[t]{2}{*}{ Budge } \\
\hline & & & & 2008 & 2013 & 2018 & 2008 & 2013 & 2018 & Push & Pull & \\
\hline \multirow[t]{2}{*}{ MYC } & $<$ & Dep & & $1.00(1.00)$ & $1.00(1.00)$ & $1.00(1.00)$ & $1.00(1.00)$ & $1.00(1.00)$ & $1.00(1.00)$ & & & $\checkmark$ \\
\hline & & & $R^{2}$ & 0.98 & 0.99 & 0.99 & 0.99 & 0.99 & 0.99 & & & \\
\hline \multirow[t]{3}{*}{ FNV } & $<$ & VA & & $1.01(1.03)$ & $1.00(.99)$ & $1.02(1.01)$ & $1.00(1.00)$ & $1.01(1.00)$ & $1.00(1.01)$ & & & $\checkmark$ \\
\hline & & MYC & & $-0.08(0 .-09)$ & $-0.06(-0.08)$ & $-0.03(-0.03)$ & $-0.03(-0.03)$ & $-0.06(-0.04)$ & $-0.03(-0.04)$ & & & $\checkmark$ \\
\hline & & & $R^{2}$ & 0.99 & 0.99 & 0.99 & 0.99 & 0.99 & 0.99 & & & \\
\hline \multirow[t]{4}{*}{ Dis_I } & $<$ & FNV & & $0.29(0.18)$ & $0.31(0.39)$ & $0.26(0.27)$ & $0.20(0.16)$ & $0.40(0.49)$ & ns & & & $\checkmark$ \\
\hline & & WUPL & & $0.58(0.67)$ & $0.69(\mathrm{~ns})$ & $0.90(0.90)$ & $0.88(0.86)$ & $0.77(0.71)$ & $0.92(0.94)$ & & $\checkmark$ & \\
\hline & & $\mathrm{RP}$ & & $0.61(0.64)$ & $0.53(0.66)$ & $0.26(0.22)$ & $0.27(0.29)$ & $0.25(0.23)$ & $0.23(0.18)$ & & & $\checkmark$ \\
\hline & & & $R^{2}$ & 0.87 & 0.97 & 0.98 & 0.87 & 0.89 & 0.90 & & & \\
\hline \multirow[t]{2}{*}{ OI } & $<$ & Dis_I & & ns & $0.74(\mathrm{~ns})$ & $0.92(0.93)$ & $0.30(0.30)$ & $0.62(0.51)$ & 0.43 (ns) & & $\checkmark$ & \\
\hline & & & $R^{2}$ & 0.065 & 0.55 & 0.84 & 0.090 & 0.39 & 0.19 & & & \\
\hline \multirow[t]{4}{*}{ FNI } & $<$ & OI & & $0.99(0.99)$ & $0.99(0.97)$ & $0.99(0.99)$ & $0.99(0.99)$ & $0.98(0.99)$ & $0.99(0.99)$ & & & \\
\hline & & $\mathrm{ECM}$ & & $0.12(0.15)$ & $0.12(0.25)$ & $0.12(0.11)$ & $0.14(0.12)$ & $0.15(0.14)$ & $0.10(0.13)$ & & & $\checkmark$ \\
\hline & & FWU & & $0.00(0.00)$ & ns & ns & $0.00(0.00)$ & ns $(0.00)$ & ns & $\checkmark$ & & \\
\hline & & & $R^{2}$ & 0.99 & 0.99 & 0.99 & 0.99 & 0.99 & 0.99 & & & \\
\hline \multirow[t]{2}{*}{ WUPL } & $<$ & FWU & & ns & $0.12(0.19)$ & ns & ns & $0.26(0.31)$ & $0.11(0.13)$ & $\checkmark$ & & \\
\hline & & & $R^{2}$ & 0.001 & 0.014 & 0.00 & 0.001 & 0.060 & 0.012 & & & \\
\hline \multirow{3}{*}{ ECM } & - & Ot_Sub_N_EU & & $0.30(0.25)$ & ns & 0.38 (ns) & $0.16(0.17)$ & $0.32(0.51)$ & $0.68(0.67)$ & $\checkmark$ & & \\
\hline & $<$ & Sub_Ca & & ns & ns & $0.03(0.05)$ & $0.02(0.02)$ & $0.48(0.37)$ & $0.33(0.51)$ & $\checkmark$ & & \\
\hline & & & $R^{2}$ & 0.10 & 0.001 & 0.15 & 0.028 & 0.36 & 0.57 & & & \\
\hline
\end{tabular}


With regards to budget items, negative values were expected for cost variables and positive values for "revenue" variables. The signs of the significant variables (OC, MYC for costs and VA, FNV, TFR, Dis_I, OI, ECM for revenues) are coherent with such expectations. The estimates' explainability is also confirmed by the values assumed by the determination coefficients $\left(R^{2}\right)$ of the dependent variables.

When looking at the revenue variables, such as the total farm revenues (TFR), it may be observed that the effect sizes of the explanatory variables significantly vary to a large extent over time and according to the group of farms (peri-urban or rural). Moreover, only the gross production value of crops (GPVC) is statistically significant for the three years under study $(2008,2013$, and 2018) for both peri-urban and rural farms. While in 2008 and 2013, the magnitude of this relationship was higher for the peri-urban farms, in 2018 , the value was considerably higher for rural farms ( 0.61 vs. 0.08 ). In 2018 , the gross production value of quality products (GPVQ) also becomes significant in generating farm income, highlighting the re-orientation of farming strategies towards quality products for both groups of farms.

In the case of peri-urban farms, the key pull factors that contribute in a very significant way to the formation of farm revenues are the public support received in the form of direct payments DP (Pil I) — the so called first pillar of the CAP — and the presence of other gainful activities (OGA). However, during the period under review, the relevance of both factors decreased. In particular, while peri-urban farms diminished their dependence on public support, an increasing relevance of rural development policy (variables Sub_Ca and Ot_Sub_N_EU) was observed for rural farms. Such results are coherent with previous studies showing the positive impacts of diversification activities on the financial performance of farms in Italy [80]. Our results show that this is particularly true for peri-urban farms, where diversification activities are adopted despite such farms often being excluded from the access to rural development policies $[3,39]$.

Among the diversification activities, there are several variables that are statistically significant and positively influence OGA for both peri-urban and rural farms, including agritourism (AgriT_R), active rent (AR), deepening activities (Deep_Ac), and other broadening activities (Ot_BRO_Ac). Even though the magnitude of these relationships varies according to explanatory variables and the reference period, it is worth emphasizing the high values of variables AgriT_R and Deep_Ac for peri-urban farms, confirming that also such farms activate a broad range of consumer-oriented diversification activities [34].

The hire of machinery for contract labor (HMCL) is another statistically significant variable showing slightly higher values for peri-urban farms. This evidence confirms that external contract services allow farmers to improve the return on investments made in agricultural machineries, as well as providing a supplement of income derived from activities carried out in other farms (e.g., transport, ploughing, and harvesting), but also as results of contracts with public authorities, especially for peri-urban farms (e.g., for landscape maintenance and snow clearing).

Several studies have also highlighted the key role played by direct selling as part of a "deepening" diversification strategy [81] that can be adopted by farmers to increase the gross farm income [82]. Recent literature also shows how the proximity to urban areas could be a factor influencing farmers in adopting direct selling $[83,84]$. Coherent with the results obtained by Uematsu and Mishra [82], in our results, direct selling variable (GPVDS) does not seem to contribute to farm revenues neither for rural nor peri-urban farms. This supports the idea that direct selling may be also adopted to reduce risks in farm management [85] or to reduce unemployment of family labor [86].

Finally, the adopted SEM model allows us to assess not only the direct impacts of explanatory variables on dependent ones, such as the OGA on TFR (in 2018 this impact was 0.03), but also significant indirect effects. For example, when looking at the 2018 values of peri-urban farms, an indirect relation that can be highlighted is between agritourism (AgriT_R) and other deepening activities (Deep_Ac) on total farm revenues (TFR): the strength of these relationships can be calculated as $0.019(0.65 \times 0.03)$ 
and $0.015(0.51 \times 0.03)$, respectively. Similarly, TFR has a strong impact on value added (VA), which in turn, impacts farm net value (FNV): in this case the magnitude of this relation is $1.62(1.59 \times 1.02)$. Another interesting indirect relation showed by the model is the influence of FNV on operating income (OI) through distributed incomes (Dis_I): the magnitude of this relationship is $0.24(0.26 \times 0.92)$. Finally, OI helps to explain the composition of farm net income (FNI).

\section{Conclusions}

An increasing number of studies are focusing attention on the multifunctional role of peri-urban farming and particularly to the economic implications of diversification processes. This article contributes to this emerging body of literature from both a methodological and content perspective.

With regards to the adopted method, to our knowledge, there have been no previous studies adopting a covariance-based SEM model to assess farm diversification processes. One of the main methodological innovations of this contribution is the application of this type of models to the FADN database, with the overall objective of estimating direct and indirect causal relationships among the multiple variables involved in the diversification process.

The application of this model to FADN data highlighted the huge potentialities while controlling for the complexity due to many theoretical interconnections among different typologies of measured variables simultaneously. Many mediation effects, and thus, indirect effects, can be reasonably tested, as well as moderator effects, rather known as interaction terms [87]. However, these latter were not considered in this study, but results strongly suggest including them in future works. For example, the public support received in the form of direct payments might be modeled as moderator by impacting the paths between the quantity of the used resources by each farm and their relative costs. This moderation has indeed the purpose to evaluate direct payments as a form of extra-savings.

Furthermore, the introduction of common (latent) factors is another strength of SEM models, especially in the (agricultural) economic field where many variables are often found highly correlated and, thus, needed to be modeled as factors. These latter can be, in turn, specified in subsequent path models as well (i.e., latent variables path models) $[19,20]$. Even though SEM models are theory-driven data, these methods start from the foundations that all measures in the real world vary and covary with each other to some extent and with even more complexity. As a consequence, the researcher has a certain amount of flexibility by making theoretical hypotheses on how and why these measures are related to each other; then, SEM models can test for these a-priori hypotheses using all the initial available information (i.e., the matrix of variances and covariances of the observed variables), which will be reduced and evaluated by a model-implied matrix of structural parameters with a certain degree of statistical likelihood.

The varieties of SEM models, as well as the associated methods of estimation while handling different kind of data and/or non-linear effects where they occur [88,89], are many e.g., [90]. They might be explored in the future also using FADN data in a longitudinal way by setting up models of economic growth at latent level [91,92].

Potential down sides of SEM models might involve the high complexity of path specifications, also at the factor level, that can cause non-convergence estimations. As a matter of fact, if, on one hand, SEM models open huge rooms to many causal specifications, on the other hand, not all is possible over and beyond the hypothesized theories. However, it is important to keep in mind that SEM models may want to approximate the reality and not to provide the best model fit to explain it [20]. Should the reality be very complex, the relative SEM model to some extent aims at revealing such complexity. In this vein, SEM models are powerful tools for the researchers to re-specify the relationships and, thus, the theory behind it, when a first model is potentially falsified until obtaining results that can satisfy the researcher and not only the cut-off criteria, because: "... a researcher must 
combine statistical measures with the human judgment when reaching a decision about a model fit" [93].

With regards to the innovativeness of the objectives and results of this article, so far, only a small number of studies have tried to assess the broad range of pull and push factors affecting the diversification process of peri-urban farms. The comparison between different typologies of farms and the use of consistent samples of observations in the FADN database allowed us to shed light on the key features characterizing diversification of peri-urban farms, as well as their potential evolution over time.

With reference to the types and magnitude of pull factors influencing diversification, the article shows the relevant economic role played by activities such as agritourism and contract services but also the increasing attention towards quality products, a trend characterizing both rural and peri-urban farms.

When looking at push factors, while for rural farms, rural development policies (II pillar of the CAP) played a consistent and increasing role in supporting income diversification, the economic performance of peri-urban farms was mainly affected by direct payments (I pillar of the CAP), a type of support that was not specifically targeted to diversification processes and that was classified as pull factor. This evidence confirms the difficulties of assessing the role of policies in the diversification process, which in some cases, could be also adopted as a survival strategy to cope with the lack of specific income support [6]. At the same time, the results of this study also show that, in front of a limited and decreasing role played by public support, in peri-urban areas, diversification processes are often strategies adopted by the most structured and market-oriented family farms, with the overall objective of developing business strategies that aim at meeting a more or less latent demand for specific goods and services expressed by urban dwellers.

In terms of policy implications, the results of this study highlight some relevant considerations. First, it shows the strategic role of diversification for both rural and periurban farms, especially of broadening activities but also of deepening ones. This result is key if one considers the peri-urban farms as large professional farms and does not include social gardens or hobby plots. Peri-urban farmers then react to the pressure of the urbanization by diversifying their activities in the direction of non-agricultural on-farm services for the citizens $[3,15,17]$. Diversification is an entrepreneurial strategy to ensure profits and redirect supply towards the cities' demand, rather than only producing food for the traditional distribution channels or re-grounding farm labor elsewhere off-farm. Second, policies do have a crucial role in enhancing these dynamics, ensuring support to specific activities through both the CAP I and II pillar box tools. In the recent literature, wide space has been given to rural development policies and their effectiveness in stimulating and enhancing diversification strategies through targeted incentives. However, I pillar support had been mostly labeled as a pure integration of farm income related to the mere status of farmers, with no influence on the decision of investments and diversification [46]. Here, it emerges that direct payments play a relevant role in diversification, both for rural farms and for peri-urban ones. Extending public support to peri-urban farms was then a coherent decision in order to support, more in general, multifunctionality and services in agriculture. This is to be kept in mind with the CAP post-2022, with national strategic plans designed and planned by national and sub-national institutions, that can target specific territorial needs with selective tools, following a participative, bottom-up, and sustainable approach to policy design and implementations.

To conclude, taking into account that this article aimed at testing two specific hypotheses (see Sections 1 and 3). Key results confirmed the first hypothesis by showing that the condition of peri-urbanity influences the combination and weight of factors driving on-farm diversification. With regard to the second hypothesis, additional studies would be necessary to fully assess to what extent peri-urbanity may change the relations and the intensity of both pull and push factors. In particular, while this study allowed us to shed light on the intensity and on (direct and indirect) relations of a broad range of pull factors, only a limited number of push factors were analyzed. This was the result of the 
low statistical significance of some variables but also to the lack of availability of relevant variables in the FADN database that could be used as proxies for push factors.

This limitation calls for additional research covering a broader range of push factors, also by integrating FADN data with other databases, in order to better capture the incentives to diversify (e.g., socio-economic and institutional settings) that affect the diversification paths of professional peri-urban farming. These merged data can be indeed modeled by a SEM approach to test those external conditions both in terms of external misspecification [94] and/or internal alteration processes [95] of a hypothesized path model.

Author Contributions: Conceptualization, R.H. and F.V.; methodology, M.V.; software, M.V.; validation, O.C. and M.V.; formal analysis, M.V.; data curation, O.C. and M.V.; writing—original draft preparation, O.C., M.V., R.H., and F.V.; writing-review and editing, O.C., M.V., R.H., and F.V. All authors have read and agreed to the published version of the manuscript.

Funding: This research received no external funding.

Institutional Review Board Statement: Not applicable.

Informed Consent Statement: Not applicable.

Data Availability Statement: Not applicable.

Conflicts of Interest: The authors declare no conflict of interest.

\section{Notes}

1 In Italy, the FADN sample selection is through a stratified random sampling without replacement that is used to represent the different types of farming (TOF) and economic size (ESU) throughout the country.

2 The number of variances and covariances of the observed variables is equal to: $p(p \pm 1) / 2$; where $p$ is the total number of observed variables [70] (p. 29).

3 The slight degreasing of the degree of freedoms was due to the presence of the so-called Heywood cases that occur when error variances can be estimated with negative values, mostly because of sampling fluctuations [19]. However, these few negative values were all found to be of low magnitude and not significant; hence, they were fixed, which constrained them to zero [20]. Furthermore, since some variances were found particularly extreme (see standard deviations in Tables 1 and 2), they have been rescaled (i.e., multiplied by a constant; we used 0.001) before conducting the analyses in order to facilitate the model convergence [20] but not affect differences among the scores [75].

4 Boostrapping analysis revealed the variable SC as statistically significant in predicting TFR for rural models b and $\mathrm{f}$, with standardized estimates, respectively, of 0.04 in 2008 and 0.052018.

\section{References}

1. Ilbery, B.W. Farm Diversification as an Adjustment Strategy on the Urban Fringe of the West Midlands. J. Rural Stud. 1991, 7, 207-218. [CrossRef]

2. Finger, R.; El Benni, N. Farm Income in European Agriculture: New Perspectives on Measurement and Implications for Policy Evaluation. Eur. Rev. Agric. Econ. 2021, 48, 253-265. [CrossRef]

3. Henke, R.; Vanni, F. Drivers of On-Farm Diversification in the Italian Peri-Urban Agriculture. Ital. Rev. Agric. Econ. 2017, 79-100. [CrossRef]

4. Bowler, I.; Clark, G.; Crockett, A.; Ilbery, B.; Shaw, A. The Development of Alternative Farm Enterprises: A Study of Family Labour Farms in the Northern Pennines of England. J. Rural Stud. 1996, 12, 285-295. [CrossRef]

5. Jongeneel, R.A.; Polman, N.B.P.; Slangen, L.H.G. Why Are Dutch Farmers Going Multifunctional? Land Use Policy 2008, 25, 81-94. [CrossRef]

6. Weltin, M.; Zasada, I.; Franke, C.; Piorr, A.; Raggi, M.; Viaggi, D. Analysing Behavioural Differences of Farm Households: An Example of Income Diversification Strategies Based on European Farm Survey Data. Land Use Policy 2017, 62, 172-184. [CrossRef]

7. Forleo, M.B.; Giaccio, V.; Mastronardi, L.; Romagnoli, L. Analysing the Efficiency of Diversified Farms: Evidences from Italian FADN Data. J. Rural Stud. 2021, 82, 262-270. [CrossRef]

8. Barrett, C.B.; Reardon, T.; Webb, P. Nonfarm Income Diversification and Household Livelihood Strategies in Rural Africa: Concepts, Dynamics, and Policy Implications. Food Policy 2001, 26, 315-331. [CrossRef]

9. Hansson, H.; Ferguson, R.; Olofsson, C.; Rantamäki-Lahtinen, L. Farmers' Motives for Diversifying Their Farm Business-The Influence of Family. J. Rural Stud. 2013, 32, 240-250. [CrossRef] 
10. Reardon, T.; Berdegué, J.; Barrett, C.B.; Stamoulis, K. Household income diversification into rural nonfarm activities. In Transforming the Rural Nonfarm Economy. Opportunities and Threads in the Developing World; Haggblade, S., Hazell, P.B.R., Reardon, T., Eds.; Johns Hopkins University Press: Baltimore, MD, USA, 2007; pp. 115-140.

11. Fritzsch, J. Is Non-Farm Income Diversification a Feasible Option for Small-Scale Farmers? An Assessment Using a Composite Fuzzy Indicator. Post Communist Econ. 2012, 24, 403-417. [CrossRef]

12. Liu, Y. Pushed out or Pulled in? Participation in Non-Farm Activities in Rural China. CAER 2017, 9, 111-129. [CrossRef]

13. Rizov, M. Pull and Push: Individual Farming in Hungary. Food Policy 2005, 30, 43-62. [CrossRef]

14. Meert, H.; Van Huylenbroeck, G.; Vernimmen, T.; Bourgeois, M.; van Hecke, E. Farm Household Survival Strategies and Diversification on Marginal Farms. J. Rural Stud. 2005, 21, 81-97. [CrossRef]

15. Zasada, I. Multifunctional Peri-Urban Agriculture-A Review of Societal Demands and the Provision of Goods and Services by Farming. Land Use Policy 2011, 28, 639-648. [CrossRef]

16. Kristensen, S.B.P.; Præstholm, S.; Busck, A.G.; Winther, L.; Fertner, C.; Vesterager, J.P.; Vejre, H. On-Farm Business Structure Diversification in Greater Copenhagen-Farmers in an Urban Landscape or Entrepreneurs in a Rural Landscape? Land Use Policy 2019, 88, 104093. [CrossRef]

17. Gullino, P.; Battisti, L.; Larcher, F. Linking Multifunctionality and Sustainability for Valuing Peri-Urban Farming: A Case Study in the Turin Metropolitan Area (Italy). Sustainability 2018, 10, 1625. [CrossRef]

18. Yoshida, S.; Yagi, H.; Kiminami, A.; Garrod, G. Farm Diversification and Sustainability of Multifunctional Peri-Urban Agriculture: Entrepreneurial Attributes of Advanced Diversification in Japan. Sustainability 2019, 11, 2887. [CrossRef]

19. Bollen, K.A. Structural Equations with Latent Variables; Wiley Press: New York, NY, USA, 1989.

20. Mueller, R.O.; Hancock, G.R. Structural Equation Modeling. In The Reviewer's Guide to Quantitative Methods in the Social Sciences, 2nd ed.; Hancock, G.R., Stapleton, L.M., Mueller, R.O., Eds.; Routledge, Taylor and Francis Group: New York, NY, USA; London, UK, 2019; pp. 445-456.

21. Boncinelli, F.; Bartolini, F.; Casini, L. Structural Factors of Labour Allocation for Farm Diversification Activities. Land Use Policy 2018, 71, 204-212. [CrossRef]

22. Lange, A.; Piorr, A.; Siebert, R.; Zasada, I. Spatial Differentiation of Farm Diversification: How Rural Attractiveness and Vicinity to Cities Determine Farm Households' Response to the CAP. Land Use Policy 2013, 31, 136-144. [CrossRef]

23. Yoshida, S.; Yagi, H.; Garrod, G. Determinants of Farm Diversification: Entrepreneurship, Marketing Capability and Family Management. J. Small Bus. Entrep. 2020, 32, 607-633. [CrossRef]

24. Morris, W.; Henley, A.; Dowell, D. Farm Diversification, Entrepreneurship and Technology Adoption: Analysis of Upland Farmers in Wales. J. Rural Stud. 2017, 53, 132-143. [CrossRef]

25. Morgan, S.L.; Marsden, T.; Miele, M.; Morley, A. Agricultural Multifunctionality and Farmers' Entrepreneurial Skills: A Study of Tuscan and Welsh Farmers. J. Rural Stud. 2010, 26, 116-129. [CrossRef]

26. Barnes, A.P.; Hansson, H.; Manevska-Tasevska, G.; Shrestha, S.S.; Thomson, S.G. The Influence of Diversification on Long-Term Viability of the Agricultural Sector. Land Use Policy 2015, 49, 404-412. [CrossRef]

27. Marques-Perez, I.; Segura, B.; Maroto, C. Evaluating the Functionality of Agricultural Systems: Social Preferences for Multifunctional Peri-Urban Agriculture. The "Huerta de Valencia" as Case Study. Span. J. Agric. Res. 2014, 12, 889. [CrossRef]

28. Yang, Z.; Cai, J.; Sliuzas, R. Agro-Tourism Enterprises as a Form of Multi-Functional Urban Agriculture for Peri-Urban Development in China. Habitat Int. 2010, 34, 374-385. [CrossRef]

29. Cerrada-Serra, P.; Colombo, L.; Ortiz-Miranda, D.; Grando, S. Access to Agricultural Land in Peri-Urban Spaces: Social Mobilisation and Institutional Frameworks in Rome and Valencia. Food Sec. 2018, 10, 1325-1336. [CrossRef]

30. La Rosa, D.; Barbarossa, L.; Privitera, R.; Martinico, F. Agriculture and the City: A Method for Sustainable Planning of New Forms of Agriculture in Urban Contexts. Land Use Policy 2014, 41, 290-303. [CrossRef]

31. Pölling, B.; Mergenthaler, M.; Lorleberg, W. Professional Urban Agriculture and Its Characteristic Business Models in Metropolis Ruhr, Germany. Land Use Policy 2016, 58, 366-379. [CrossRef]

32. Marino, D.; Mastronardi, L.; Giannelli, A.; Giaccio, V.; Mazzocchi, G. Territorialisation Dynamics for Italian Farms Adhering to Alternative Food Networks. Bull. Geogr. Soc. Econ. Ser. 2018, 40, 113-131. [CrossRef]

33. Paül, V.; McKenzie, F.H. Peri-Urban Farmland Conservation and Development of Alternative Food Networks: Insights from a Case-Study Area in Metropolitan Barcelona (Catalonia, Spain). Land Use Policy 2013, 30, 94-105. [CrossRef]

34. Pölling, B.; Mergenthaler, M. The Location Matters: Determinants for "Deepening" and "Broadening" Diversification Strategies in Ruhr Metropolis' Urban Farming. Sustainability 2017, 9, 1168. [CrossRef]

35. Vandermeulen, V.; Verspecht, A.; Van Huylenbroeck, G.; Meert, H.; Boulanger, A.; Van Hecke, E. The Importance of the Institutional Environment on Multifunctional Farming Systems in the Peri-Urban Area of Brussels. Land Use Policy 2006, 23, 486-501. [CrossRef]

36. Vecchio, Y.; Adinolfi, F.; Albani, C.; Bartoli, L.; De Rosa, M. Boosting Sustainable Innovation in Densely Populated Areas: A Milieux Innovateurs Approach. Sustainability 2020, 12, 9131. [CrossRef]

37. Heimlich, R.E.; Barnard, C.H. Agricultural adaptation to urbanisation? Farm types and agricultural sustainability in US metropolitan areas. In Rural Sustainable Development in America, 2nd ed.; Audrina, I., Ed.; Wiley and Sons: New York, NY, USA, 1997; pp. 283-303.

38. Pascucci, S. Agricoltura periurbana e strategie di sviluppo rurale: Una riflessione. QA Riv. Assoc. Rossi-Doria $2008,2,127-151$. 
39. Henke, R.; Vanni, F. Peri-urban agriculture: An analysis of farm typologies in Italy. New Medit. 2017, 16, 11-18.

40. Wästfelt, A.; Zhang, Q. Reclaiming Localisation for Revitalising Agriculture: A Case Study of Peri-Urban Agricultural Change in Gothenburg, Sweden. J. Rural Stud. 2016, 47, 172-185. [CrossRef]

41. Wojewodzic, T.; Sroka, W.; Mikolajczyk, J. Dynamics and variability in income from farming in farms operating in metropolitan areas in Poland. Ann. Pol. Assoc. Agric. Agrobus. Econ. 2019, 21. [CrossRef]

42. Wojewodzic, T.; Sroka, W. Commercial Farms in Polish Metropolitan Areas: Changes in Production Factors [Towarowe Gospodarstwa Rolne Na Obszarach Metropolitalnych w Polsce: Zmiany Zasobów Czynników Produkcji]. Wieś i Rolnictwo 2018, 181, 91-110. [CrossRef]

43. Coppola, A.; Scardera, A.; Amato, M.; Verneau, F. Income Levels and Farm Economic Viability in Italian Farms: An Analysis of FADN Data. Sustainability 2020, 12, 4898. [CrossRef]

44. Scardera, A. Gli Strumenti Decisionali per le Aziende Agricole: Il Bilancio Semplificato; INEA: Lamezia Terme, Italy, 2014.

45. Ciliberti, S.; Frascarelli, A. The CAP 2013 Reform of Direct Payments: Redistributive Effects and Impacts on Farm Income Concentration in Italy. Agric. Econ. 2018, 6, 19. [CrossRef]

46. Brady, M.; Hristov, J.; Höjgård, S.; Jansson, T.; Johansson, H.; Nordin, I.; Rabinowicz, E. Impacts of Direct Payments, Lessons for CAP post-2020 from a Quantitative Analysis; Report 2017:2; AgriFood Economics Centre: Lund, Sweden, 2017.

47. Severini, S.; Tantari, A.; Di Tommaso, G. Do CAP Direct Payments Stabilise Farm Income? Empirical evidences from a Constant Sample of Italian Farms. Agric. Econ. 2016, 4, 6. [CrossRef]

48. Le, L.H.; Le, T.N. Determinants of Income Diversification among Rural Households in the Mekong River Delta: The Economic Transition Period. J. Asian Financ. Econ. Bus. 2020, 7, 291-304. [CrossRef]

49. Finocchio, R.; Esposti, R. Determinants of Farm Diversification and Interaction with the CAP. An Application to FADN of Marche Region (Italy). European Association of Agricultural Economists (EAAE). In Proceedings of the 2008 International Congress, Ghent, Belgium, 26-29 August 2008.

50. Barbieri, C.; Mahoney, E. Why Is Diversification an Attractive Farm Adjustment Strategy? Insights from Texas Farmers and Ranchers. J. Rural Stud. 2009, 25, 58-66. [CrossRef]

51. Vik, J.; McElwee, G. Diversification and the Entrepreneurial Motivations of Farmers in Norway. J. Small Bus. Manag. 2011, 49, 390-410. [CrossRef]

52. Abdulai, A.; Delgado, C.L. Determinants of Nonfarm Earnings of Farm-Based Husbands and Wives in Northern Ghana. Am. J. Agric. Econ. 1999, 81, 117-130. [CrossRef]

53. Meraner, M.; Heijman, W.; Kuhlman, T.; Finger, R. Determinants of Farm Diversification in the Netherlands. Land Use Policy 2015, 42, 767-780. [CrossRef]

54. Benjamin, C. Farm Work, off-Farm Work, and Hired Farm Labour: Estimating a Discrete-Choice Model of French Farm Couples' Labour Decisions. Eur. Rev. Agric. Econ. 2006, 33, 149-171. [CrossRef]

55. Storti, D. Le aree rurali nella nuova programmazione. Agriregionieuropa 2013, 35, 60-62.

56. Rete Rurale Nazionale. Zonizzazione e Cartografia. 2014. Available online: https://www.reterurale.it/areerurali (accessed on 2 November 2020).

57. Opitz, I.; Berges, R.; Piorr, A.; Krikser, T. Contributing to Food Security in Urban Areas: Differences between Urban Agriculture and Peri-Urban Agriculture in the Global North. Agric. Hum. Values 2016, 33, 341-358. [CrossRef]

58. Cagliero, R.; Cisilino, F.; Scardera, A. L'utilizzo della RICA per la Valutazione di Programmi di Sviluppo Rurale; Rete Rurale Nazionale: Roma, Italy, 2010.

59. Low, H.; Meghir, C. The Use of Structural Models in Econometrics. J. Econ. Perspect. 2017, 31, 33-58. [CrossRef]

60. Li, H.; Liu, Y.; Peng, K. Characterizing the Relationship between Road Infrastructure and Local Economy Using Structural Equation Modeling. Transport. Policy 2018, 61, 17-25. [CrossRef]

61. Angelini, M.E.; Heuvelink, G.B.M.; Kempen, B. Multivariate Mapping of Soil with Structural Equation Modelling: Multivariate Soil Mapping Using SEM. Eur. J. Soil Sci. 2017, 68, 575-591. [CrossRef]

62. Santibáñez-Andrade, G.; Castillo-Argüero, S.; Vega-Peña, E.V.; Lindig-Cisneros, R.; Zavala-Hurtado, J.A. Structural Equation Modeling as a Tool to Develop Conservation Strategies Using Environmental Indicators: The Case of the Forests of the Magdalena River Basin in Mexico City. Ecol. Indic. 2015, 54, 124-136. [CrossRef]

63. Babatunde, R.O.; Qaim, M. Patterns of Income Diversification in Rural Nigeria: Determinants and Impacts. Q. J. Int. Agric. 2009, 48, 4 .

64. Bojnec, Š.; Latruffe, L. Determinants of Technical Efficiency of Slovenian Farms. Post Communist Econ. 2009, 21, 117-124. [CrossRef]

65. Rønning, L.; Kolvereid, L. Income Diversification in Norwegian Farm Households: Reassessing Pluriactivity. Int. Small Bus. J. 2006, 24, 405-420. [CrossRef]

66. Culas, R.J. Causes of Farm Diversification over Time: An Australian Perspective on an Eastern Norway Model. AFBM J. $2006,3,1$.

67. Schumacker, R.E.; Lomax, R.G. A Beginner's Guide to Structural Equation Modeling, 4th ed.; Routledge: New York, NY, USA, 2016.

68. Wright, S. The Method of Path Coefficients. Ann. Math. Stat. 1934, 5, 161-215. [CrossRef]

69. Wolfle, L.M. Sewall Wright on the Method of Path Coefficients: An Annotated Bibliography. Struct. Equ. Model. Multidiscip. J. 1999, 6, 280-291. [CrossRef]

70. Byrne, B.M. Structural Equation Modeling with LISREL, PRELIS and SIMPLIS: Basic Concepts, Applications, and Programming; Lawrence Erlbaum Associates (LEA), Publishers: Mahwah, NJ, USA, 1998. 
71. Satorra, A.; Bentler, P.M. Corrections to test statistics and standard errors in covariance structure analysis. In Latent Variable Analysis: Applications for Developmental Research; von Eye, A., Clogg, C.C., Eds.; Sage Publications: Thousand Oaks, CA, USA, 1994; pp. 399-419.

72. Finney, S.J.; Di Stefano, C. Nonnormal and categorical data in structural equation modeling. In Structural Equation Modeling: A Second Course; Hancock, G.R., Mueller, R.O., Eds.; Information Age Publishing: Greenwich, CT, USA, 2013 ; pp. $267-309$.

73. Fan, Y.; Chen, J.; Shirkey, G.; John, R.; Wu, S.R.; Park, H.; Shao, C. Applications of Structural Equation Modeling (SEM) in Ecological Studies: An Updated Review. Ecol. Process. 2016, 5, 19. [CrossRef]

74. Hu, L.; Bentler, P.M. Cutoff Criteria for Fit Indexes in Covariance Structure Analysis: Conventional Criteria versus New Alternatives. Struct. Equ. Model. Multidiscip. J. 1999, 6, 1-55. [CrossRef]

75. Kline, B.R. Principles and Practice of Structural Equation Modeling, 3rd ed.; The Guilford Press: New York, NY, USA, 2011.

76. Schermelleh-Engel, K.; Moosbruger, H.; Müller, H. Evaluating the Fit of Structural Equation Models: Tests of Significance and Descriptive-of-Fit Measures. Methods Psychol. Res. Online 2003, 8, $23-74$.

77. Moshagen, M.; Erdfelder, E. A New Strategy for Testing Structural Equation Models. Struct. Equ. Model. Multidiscip. J. 2016, 23, 54-60. [CrossRef]

78. Jöreskog, K.G.; Sörbom, D. LISREL 9.30 for Windows; Computer Software; Scientific Software International, Inc.: Skokie, IL, USA, 2017.

79. Hair, J.F.; Sarstedt, M.; Ringle, C.M.; Gudergan, S.P. Advanced Issues in Partial Least Squares Structural Equation Modeling; Sage: Thousand Oaks, CA, USA, 2018.

80. Salvioni, C.; Henke, R.; Vanni, F. The Impact of Non-Agricultural Diversification on Financial Performance: Evidence from Family Farms in Italy. Sustainability 2020, 12, 486. [CrossRef]

81. Van Der Ploeg, J.D.; Roep, D. Multifunctionality and rural development: The actual situation in Europe. In Multifunctional Agriculture. A New Paradigm for European Agriculture and Rural Development; Van Huylenbroeck, G., Durand, G., Eds.; Ashgate: Aldershot, UK, 2003.

82. Uematsu, H.; Mishra, A.K. Use of Direct Marketing Strategies by Farmers and Their Impact on Farm Business Income. Agric. Resour. Econ. Rev. 2011, 40,1-19. [CrossRef]

83. Corsi, A.; Frontuto, V.; Novelli, S. What Drives Farm Structural Change? An Analysis of Economic, Demographic and Succession Factors. Agriculture 2021, 11, 438. [CrossRef]

84. Jarosz, L. The City in the Country: Growing Alternative Food Networks in Metropolitan Areas. J. Rural Stud. 2008, 24, 231-244. [CrossRef]

85. Farmer, J.R.; Betz, M.E. Rebuilding Local Foods in Appalachia: Variables Affecting Distribution Methods of West Virginia Farms. J. Rural Stud. 2016, 45, 34-42. [CrossRef]

86. Aguglia, L.; De Santis, F.; Salvioni, C. Direct selling: A marketing strategy to shorten distances between production and consumption. In A Resilient European Food Industry in a Challenging World; Baourakis, G., Mattas, K., Zopounidis, C., van Dijk, G., Eds.; NOVA: New York, NY, USA, 2011; pp. 1-16.

87. Preacher, K.J.; Rucker, D.D.; Hayes, A.F. Addressing Moderated Mediation Hypotheses: Theory, Methods, and Prescriptions. Multivar. Behav. Res. 2007, 42, 185-227. [CrossRef]

88. Harring, J.R.; Weiss, B.A.; Hsu, J.-C. A Comparison of Methods for Estimating Quadratic Effects in Nonlinear Structural Equation Models. Psychol. Methods 2012, 17, 193-214. [CrossRef]

89. Marsh, H.W.; Wen, Z.; Hau, K.-T.; Nagengast, B. Structural Equation Models of Latent Interaction and Quadratic Effects. In Structural Equation Modeling: A Second Course; Hancock, G.R., Mueller, R.O., Eds.; Information Age Publishing: Greenwich, CT, USA, 2013; pp. 267-309.

90. Muthén, L.K.; Muthén, B.O. Mplus User's Guide, 8th ed.; Muthén \& Muthén: Los Angeles, CA, USA, 2017.

91. Bollen, K.A.; Curran, P.J. Latent Curve Models: A Structural Equation Perspective; Wiley: New York, NY, USA, 2006.

92. Duncan, T.E.; Duncan, S.C.; Stryker, L.A. An Introduction to Latent Variable Growth Curve Modeling: Concepts, Issues, and Applications, 2nd ed.; Lawrence Erlbaum: Mahwah, NJ, USA, 2006.

93. Chen, F.; Curran, P.J.; Bollen, K.A.; Kirby, J.; Paxton, P. An Empirical Evaluation of the Use of Fixed Cutoff Points in RMSEA Test Statistic in Structural Equation Models. Sociol. Methods Res. 2008, 36, 462-494. [CrossRef] [PubMed]

94. Harring, J.R.; McNeish, D.M.; Hancock, G.R. Using phantom variables in structural equation modeling to assess model sensitivity to external misspecification. Psychol. Methods 2017, 22, 616-631. [CrossRef] [PubMed]

95. Vassallo, M. Exploring boundaries of correct specifications in cognitive causal models: Phantom path analysis may help. Test. Psychom. Methodol. Appl. Psychol. 2020, 27, 21-42. [CrossRef] 